
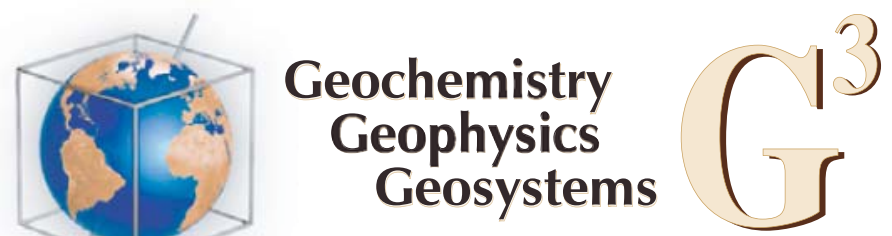

Published by AGU and the Geochemical Society

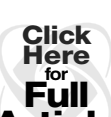

Article

\title{
Late Cretaceous arc development on the SW margin of the Caribbean Plate: Insights from the Golfito, Costa Rica, and Azuero, Panama, complexes
}

\author{
David M. Buchs and Richard J. Arculus \\ Research School of Earth Sciences, Australian National University, Canberra, ACT 0200, Australia \\ (trachybasalt@gmail.com)
}

\author{
Peter O. Baumgartner and Claudia Baumgartner-Mora \\ Institut de Géologie et Paléontologie, Université de Lausanne, CH-1015 Lausanne, Srwitzerland
}

\author{
Alexey Ulianov \\ Institut de Minéralogie et Géochimie, Université de Lausanne, CH-1015 Lausanne, Switzerland
}

[1] The processes of arc initiation at the margin of an oceanic plateau are remarkably well preserved along the southern coastline of eastern Costa Rica and western Panama. We present new results of a combined tectonostratigraphic and petrologic study with which protoarc initiation (75-73 Ma) at the margin of an oceanic plateau (89-85 Ma) is documented. Dykes of protoarc igneous rocks within the plateau and occurrences of protoarc igneous rocks are widely distributed. These types of field observations, geochemical data, and paleontologic ages for Late Cretaceous to Eocene fore-arc rocks of the Golfito Complex and Azuero Marginal Complex (southern Costa Rica and western Panama) provide the first direct evidence that a Coniacian-early Santonian oceanic plateau forms the arc basement. Stratigraphic and geochemical constraints from Golfito and Azuero indicate subduction initiation in south Central America, associated with geochemically distinctive suprasubduction igneous rocks, occurred in the late Campanian along the margin of the newly defined Azuero Plateau. Overall, the Golfito Complex and Azuero Marginal Complex provide a significant opportunity for exploration of petrologic mechanisms linking some oceanic plateaus to the growth of continents. The Azuero Plateau may extend further toward the Colombian Basin and forms thickened Caribbean crust. It served as a nucleus for accretion of additional oceanic plateaus, seamounts, and oceanic islands of Pacific origins.

Components: 19,800 words, 12 figures, 4 tables.

Keywords: protoarc; oceanic plateau; arc initiation; volcanic arc; Caribbean; Central America.

Index Terms: 8185 Tectonophysics: Volcanic arcs (1207); 3038 Marine Geology and Geophysics: Oceanic plateaus and microcontinents (1207); 7240 Seismology: Subduction zones (1207).

Received 14 October 2009; Revised 12 March 2010; Accepted 23 March 2010; Published 10 July 2010. 
Buchs, D. M., R. J. Arculus, P. O. Baumgartner, C. Baumgartner-Mora, and A. Ulianov (2010), Late Cretaceous arc development on the SW margin of the Caribbean Plate: Insights from the Golfito, Costa Rica, and Azuero, Panama, complexes, Geochem. Geophys. Geosyst., 11, Q07S24, doi:10.1029/2009GC002901.

Theme: Central American Subduction System

Guest Editors: G. Alvarado, K. Hoernle, and E. Silver

\section{Introduction}

[2] Volcanic arcs are complex systems that are initiated and evolve in response to the regional tectonic/geodynamic régime [Gurnis et al., 2004] and nature of the subducting plate [e.g., Pearce and Peate, 1995]. Subduction initiation is characterized by petrologically distinctive suprasubduction rock types [Pearce et al., 1992] that are generally obscured by younger deposits in mature arcs. Understanding initiation and early evolution of arcs depends on studies of these infant arc rocks; fortuitous exposures in southern Central America provide an important opportunity for such effort. The volcanic arcs and related subduction zones of this region have been the subject of intense study [e. g., Ranero and von Huene, 2000; Carr et al., 2007; Hoernle et al., 2008], but the early history of the area is relatively poorly understood. We present new data (tectonostratigraphic and geochemical) for exposures in the current fore arc between southern Costa Rica and western Panama, to obtain insight into the origins of the South Central American Arc and the nature of the arc basement. We propose the arc initiated in the late Campanian ( 75-73 Ma) on top of a Coniacian-Santonian ( 89-85 Ma) oceanic plateau that formed a margin of the Caribbean Plate. We provide the first recognition of the earliest arc igneous rocks formed through suprasubduction magmatism along the margins of this plateau. These rocks offer an opportunity to test possible roles of oceanic plateaus in the growth of continents (i.e., continentalization of the oceanic crust) [e.g., Ben-Avraham et al., 1981].

\section{Regional Setting}

[3] The South Central American Arc lies on the Panama Microplate (also described as Chorotega and Choco blocks) (Figure 1). The Panama Microplate is a SW extension of the Caribbean Plate bounded by thrust zones and transforms, situated at the junction of five plates and a tectonic block: the Caribbean Plate, South American Plate, Chortis Block, Cocos Plate, and Nazca Plate (Figures 1 and 2).
[4] The Caribbean Plate is generally regarded as an archetypical example of a large igneous province or oceanic plateau: normal oceanic crust partly thickened by intraplate magmatism [e.g., Sinton et al., 1998; Kerr, 2003; Hoernle et al., 2004] (Figure 1). Most authors consider the Caribbean Plateau (or Caribbean Large Igneous Province, CLIP) formed in the Pacific in the latest Cretaceous before being incorporated between the Americas in response to the opening of the Atlantic Ocean and associated westward migration of the Americas [e.g., Burke, 1988; Pindell et al., 2005, 2006; Mann, 2007; Pindell and Kennan, 2009]. Alternate models consider the CLIP formed in situ [e.g., Meschede and Frisch, 1998; James, 2006].

[5] Boundaries of the Panama Microplate include the North Panama Deformed Belt [Adamek et al., 1988; Silver et al., 1990] and a diffuse thrust belt in the Cordillera Central of Costa Rica [Marshall et al., 2000; Denyer and Alvarado, 2007], controlled by active convergence of the Caribbean Plate toward Central America [Trenkamp et al., 2002]. The eastern edge of the Panama Microplate is suturing with the continental South American Plate [Taboada et al., 2000; Trenkamp et al., 2002]. The continental Chortis Block is in contact with the NW edge of the Panama Microplate along a Late Cretaceous suture zone exposing an assemblage of pre-Campanian oceanic terranes known as the Mesquito Composite Oceanic Terrane [Baumgartner et al., 2008]. The southern boundary of the Panama Microplate is a subduction zone involving the downgoing Cocos and Nazca oceanic plates.

[6] The Cocos and Nazca oceanic plates include seamounts and aseismic ridges (drowned intraplate volcanoes) formed in association with the Galápagos Hot spot and oceanic transforms [e.g., von Huene et al., 1995, 2000; Werner et al., 1999]. Subduction of the seamounts and transforms under the Panama Microplate triggers local uplift of the outer margin of the overriding plate as close as $20 \mathrm{~km}$ from the trench [e.g., Fisher et al., 1998; Gardner et al., 2001; MacMillan et al., 2004; Sak et al., 2009]. Deep sections of this overriding 


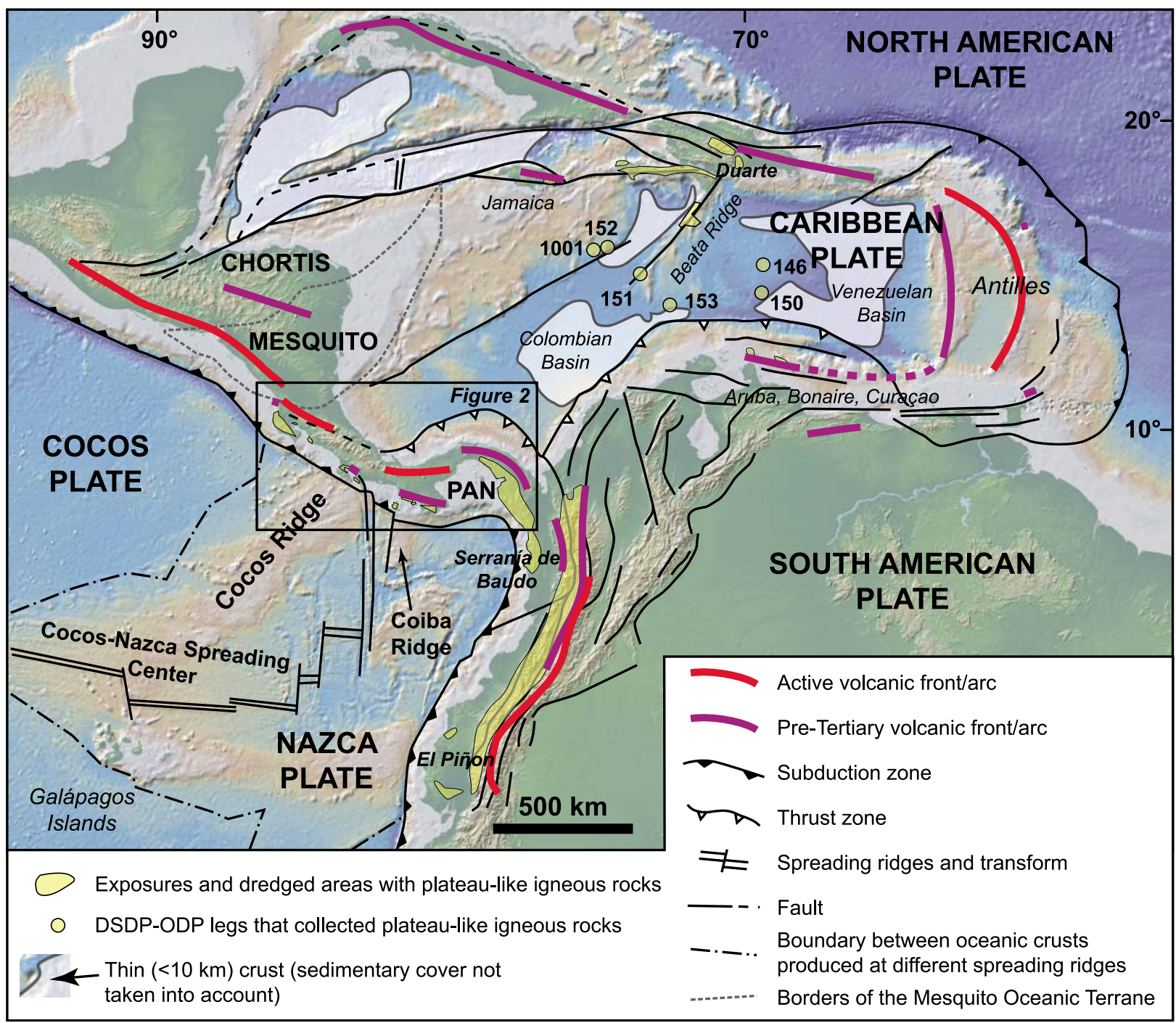

Figure 1. Tectonic setting of the Panama Microplate (PAN). Colored background map from GeoMapApp (http:// new.geomapapp.org/, 2007). Lineaments and plate limits modified after Meschede and Barckhausen [2001] and Pindell et al. [2005, 2006]. Areas of thin "normal" oceanic crust after Mauffret and Leroy [1997].

plate expose complexes of oceanic and arc assemblages, unconformably overlain by fore-arc sediments we term overlap sequences. Our study focused on some of the oceanic assemblages between southern Costa Rica and western Panama.

\section{Geologic Overview of the South Central American Fore Arc, With Focus on the Nature of the Arc Basement and Arc Initiation}

\subsection{Nature of the Arc Basement}

[7] The southern Central America fore arc includes uplifted igneous and accretionary complexes made of Early Cretaceous to Miocene seamounts, oceanic plateaus, and sediments (Figure 2; see Denyer et al. [2006], Hoernle and Hauff [2007], and Denyer and Gazel [2009] for a general review). Some igneous complexes along the margin from northern Costa Rica to western Panama have geochemical affinities with oceanic plateaus [e.g., Hoernle and Hauff, 2007, and references therein], with ages ranging from 139 to $71 \mathrm{Ma}\left({ }^{40} \mathrm{Ar} /{ }^{39} \mathrm{Ar}\right.$ ) [Sinton et al., 1997; Hoernle et al., 2002, 2004]. These complexes are considered to be part of the CLIP on the basis of age and chemistry [e.g., Sinton et al., 1997, 1998]. However, little attempt has been made to use sedimentary and structural observations to further constrain this interpretation. For example, new tectonostratigraphic data suggest the Nicoya Complex 


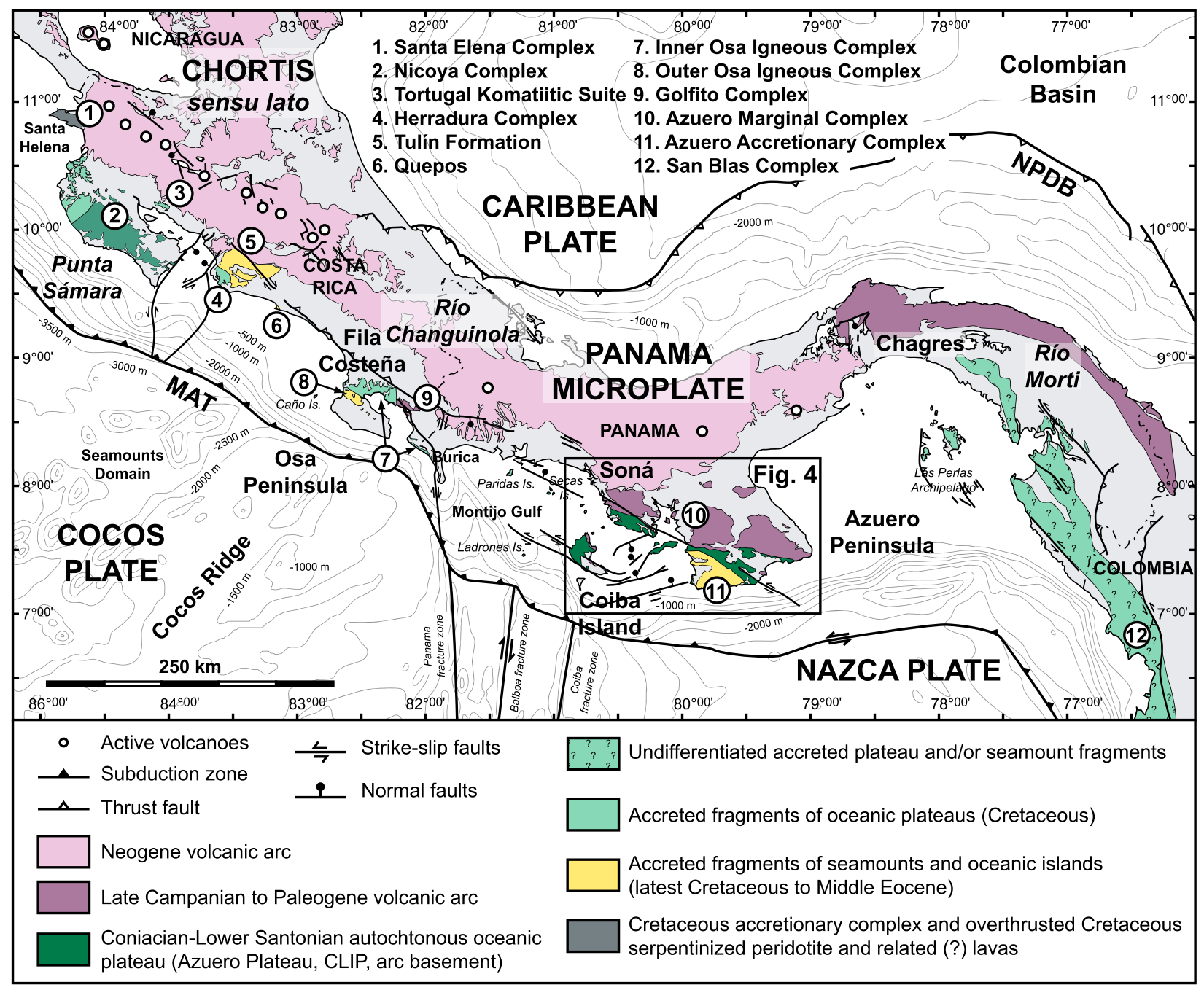

Figure 2. Simplified geological map of south Central America modified after Buchs et al. [2009]. Bathymetry based on Smith and Sandwell [1997]. Quaternary faults from Cowan et al. [1998], Montero et al. [1998], and Paris et al. [2000]. Numbers indicate igneous complexes exposed along the fore arc; NPDB, North Panama Deformed Belt; MAT, Mid American Trench. Autochthonous and accreted oceanic complexes are defined on the basis of our new results and data from previous contributions [Bandy and Casey, 1973; Baumgartner et al., 1984, 2008; Di Marco, 1994; Arias, 2003; Flores, 2003; Bandini et al., 2008; Buchs, 2008; Buchs et al., 2009].

(northern Costa Rica) and the Inner Osa Igneous Complex (southern Costa Rica) formed in the Pacific realm as distinct oceanic plateaus before being accreted to the Caribbean margin [Bandini et al., 2008; Baumgartner et al., 2008; Buchs et al., 2009]. These complexes are therefore not part of the CLIP, even though they have ages and geochemical affinities partly similar to igneous rocks from the Caribbean Oceanic Plateau.

[8] Extension of plateau-like igneous complexes under the South Central American Arc (toward the Caribbean) is poorly constrained. Seismic profiles across the volcanic front in northern Costa Rica show the arc basement is a thickened oceanic crust, distinct from the Nicaraguan basement, and potentially representing the western extension of the CLIP beneath the volcanic front [Bowland and Rosencrantz, 1988; Bowland, 1993; Sallarès et al., 1999, 2001; Walther et al., 2000; Auger et al., 2007; Flueh and von Huene, 2007; MacKenzie et al., 2008]. This interpretation is consistent with the geochemical characteristics of recent arc magmas, which preclude a continental origin for the arc basement [e.g., Feigenson et al., 2004; Gazel et al., 2009], though ongoing continentalization of an oceanic basement has been suggested by some [e.g., 
Vogel et al., 2004]. Existence of a Pacific oceanic plateau forming the bulk of the Caribbean Plate supports the hypothesis that the South Central American Arc formed in the latest Cretaceous on top of the SW edge of the CLIP [e.g., Deering et al., 2007; Geldmacher et al., 2008; Wörner et al., 2009; Wegner et al., 2010]. We provide here the first direct observations supporting this hypothesis.

\subsection{Previous Constraints on the South Central American Arc Initiation}

[9] While Cenozoic arc volcanism in south Central America has been studied for a long time [e.g., de Boer et al., 1995; Gazel et al., 2009], arc initiation has been poorly constrained, because older arc products are buried under younger volcanism (Costa Rica) or located in remote areas (eastern Panama) (Figure 2). Deciphering provenance and age of the volcanic component of clastic sediments is critical in this regard. In northern Costa Rica (Nicoya Peninsula) for example, Albian to Paleogene detrital deposits contain arc-derived sand grains [Lundberg, 1982, 1991; Rivier, 1983; Baumgartner et al., 1984; Astorga, 1987; Calvo and Bolz, 1994]. New tectonostratigraphic interpretation of Punta Samara of the Nicoya Peninsula shows the earliest record of arc-derived material is Coniacian $(89.3$ to $85.8 \mathrm{Ma})$ [cf. Patino et al., 2004; Flores, 2003; Bandini et al., 2008]. This material is unrelated to the latest Cretaceous to Paleogene volcanic arc of southern Central America, and likely formed in an intraoceanic arc in the Pacific realm [Baumgartner et al., 2008]. In southern Costa Rica, upper Campanian arc-derived tuffaceous sediments are exposed in the back arc [Mende, 2001] close to contemporaneous differentiated volcanic rocks of the Río Changuinola [Fisher and Pessagno, 1965]. In the fore-arc area, the oldest reported occurrence of arcderived sediments is Paleocene [Di Marco, 1994].

[10] In Panama, new ${ }^{40} \mathrm{Ar} /{ }^{39} \mathrm{Ar}$ ages of arc-related igneous rocks [Lissinna et al., 2002, 2006; Lissinna, 2005; Wörner et al., 2005, 2006, 2009; Wegner et al., 2010] agree with previous stratigraphic determinations [del Giudice and Recchi, 1969; Maury et al., 1995] and indicate the arc is at least Maastrichtian ( 71 Ma) in age. On the basis of ages and geochemical constraints from central and western Panama, it has been proposed the "early" Maastrichtian arc rocks were emplaced on top of the CLIP, with involvement of a large spectrum of mantle compositions at the onset of arc magmatism [Wörner et al., 2009; Wegner et al., 2010]. It was also proposed that suprasubduction and CLIP magmatisms were coeval at the onset of arc magmatism in the Azuero area and that the earliest South Central American Arc represents a transition from plume activity to subduction [Wegner et al., 2010]. In contrast, we show here the onset of arc magmatism occurred at least $\sim 2 \mathrm{Ma}$ earlier, in the late Campanian ( 75$73 \mathrm{Ma}$ ). The earliest arc magmatism corresponds to a protoarc not previously recognized, which was emplaced into and on top of a Late Cretaceous oceanic plateau. Formation of the oceanic plateau had ceased in the studied area prior to subduction initiation. Composition of the earliest suprasubduction magmas in south Central America is consistent with occurrence of a compositionally broadly homogeneous mantle wedge at the onset of subduction, which was initially associated with formation of the oceanic plateau.

\section{Analytical Techniques}

[11] Our study and interpretations are based on integration of (1) $>9$ months of field work, (2) petrographic observations of $\sim 700$ samples, (3) 195 geochemical analyses of rocks from distinct complexes, (4) biochronological dating of sediments, and (5) remote and on-land analysis of structures. Using this approach, we define a new tectonostratigraphy for the south Costa Rican to western Panamanian fore arc. Interpretation of the geochemical data is integrated with this tectonostratigraphy.

[12] Igneous samples (75) were chosen for their relative freshness on the basis of microscope observations of glasses and minerals. Samples were cut, crushed, powdered and analyzed at the Institut de Minéralogie et Géochimie (Université de Lausanne, Switzerland). Rock powders were prepared with a WC mill. Replicate analyses of some depleted samples prepared with an agate mill show with the exception of Ta, the use of the WC mill did not introduce detectable contamination (Ta was not used in geochemical interpretations). Six grams of Li tetraborate was added to $1.2 \mathrm{~g}$ of rock powder and fused in a Pt crucible to obtain lithium tetraborate glass beads. Whole-rock major element abundances were determined on the lithium tetraborate glass beads using a Philips PW2400 X-ray fluorescence spectrometer. Major and minor element contents were recalculated on an anhydrous base for interpretations. Trace element contents were determined using a laser ablation inductively coupled plasma source mass spectrometer (LA-ICP-MS) 


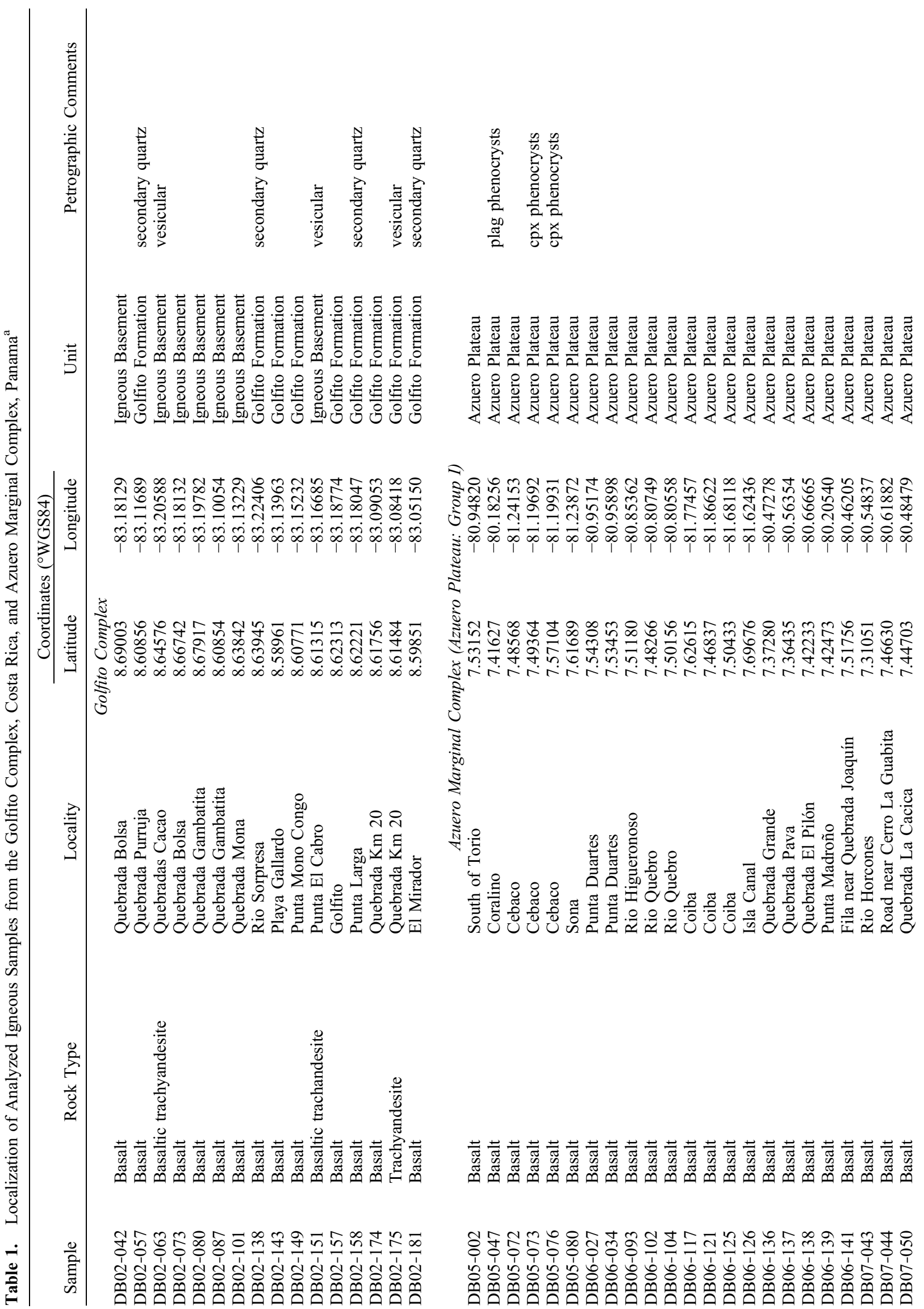




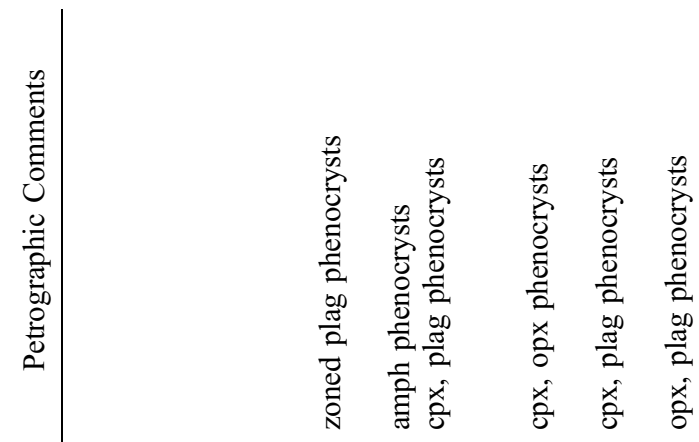

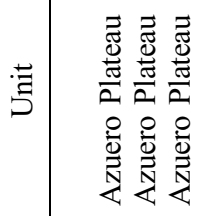

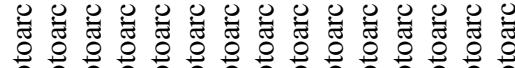

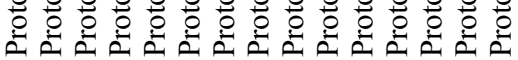

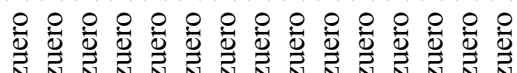

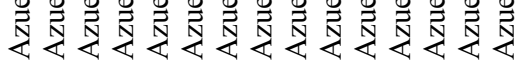

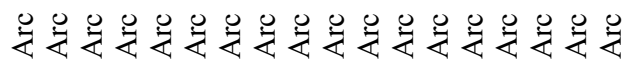

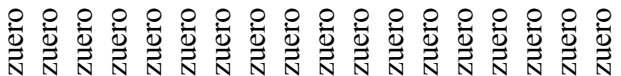

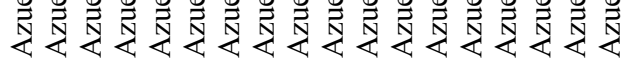

$\approx$

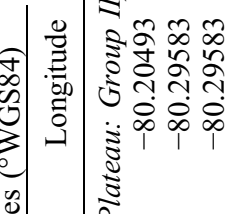

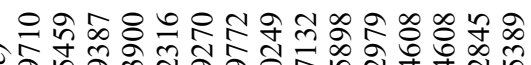

ड़ें

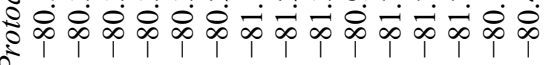

离

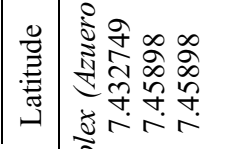

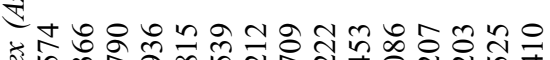

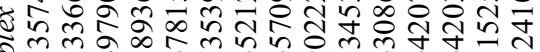

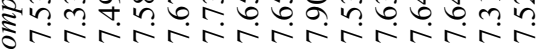

竎

¿

๖

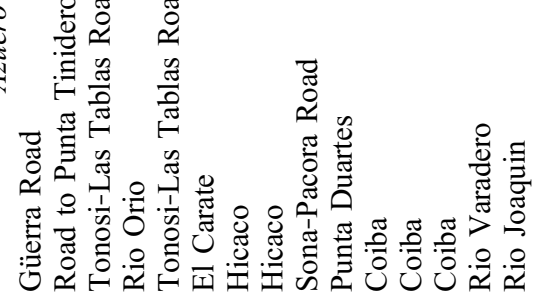

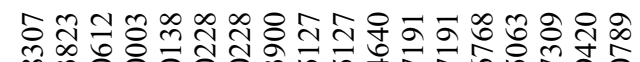

。

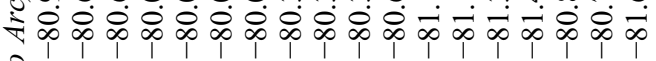

离

ॐำ

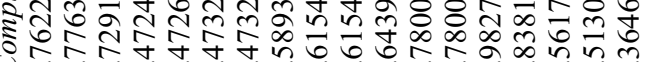

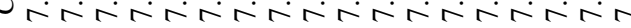

కี

है

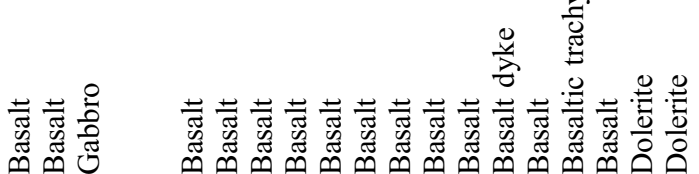

离

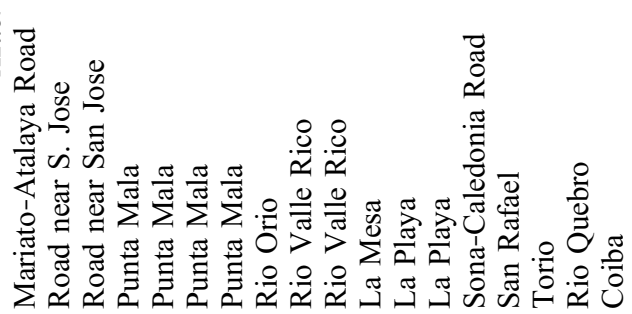

ㄱ.

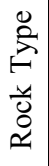
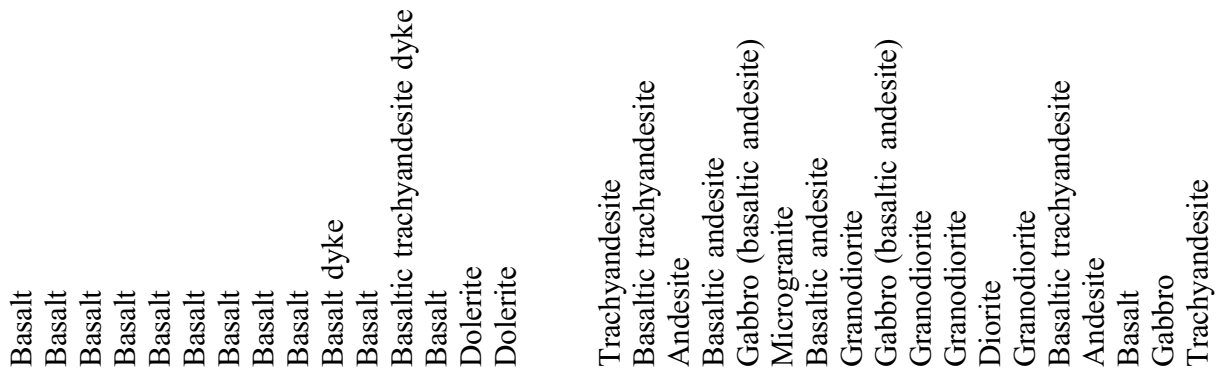

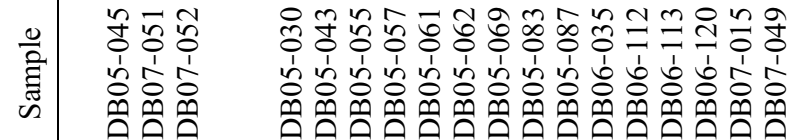

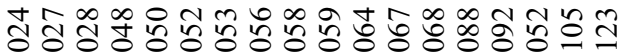

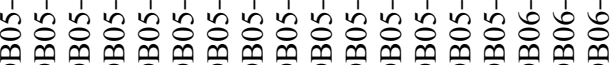

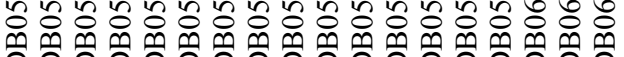




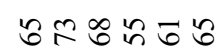

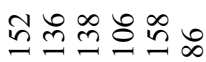

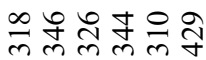

ำํำำำ

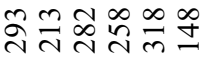

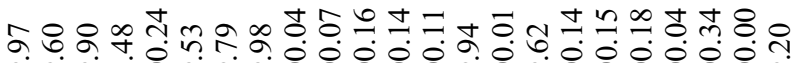

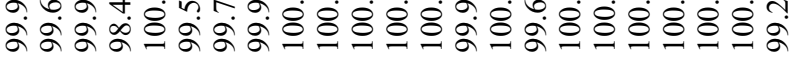

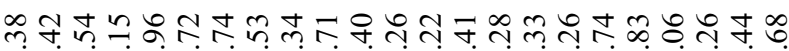

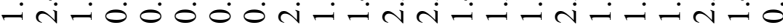

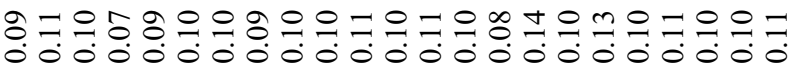

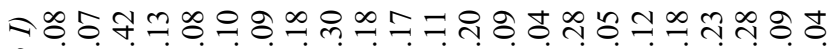
0.0000000000000000000000 密 ثิ

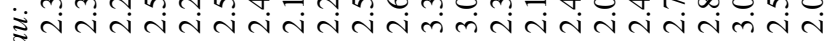

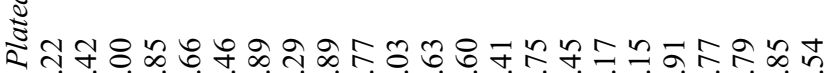

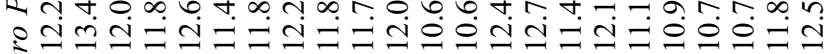
离

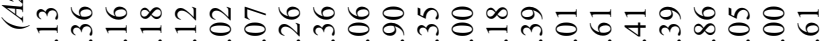

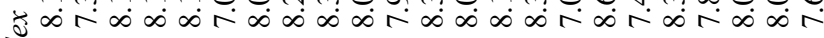
齐

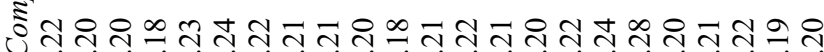
-00000000000000000000000 §

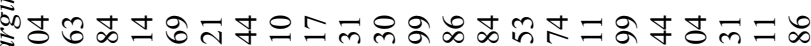

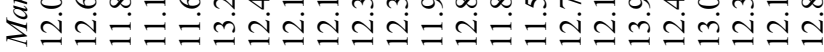
인

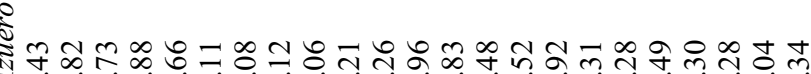

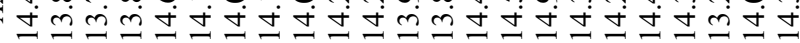

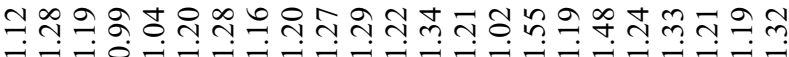

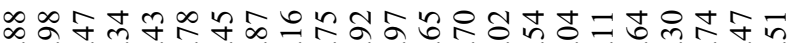

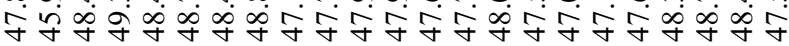

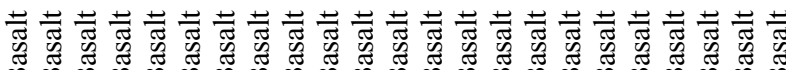

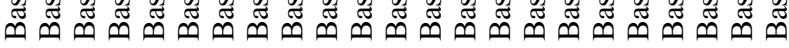

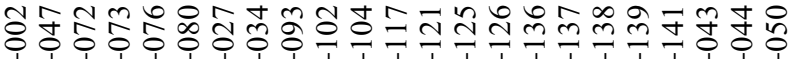

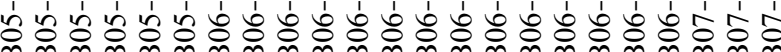

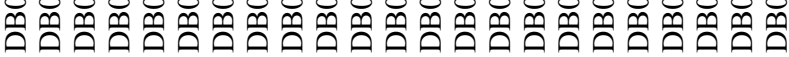




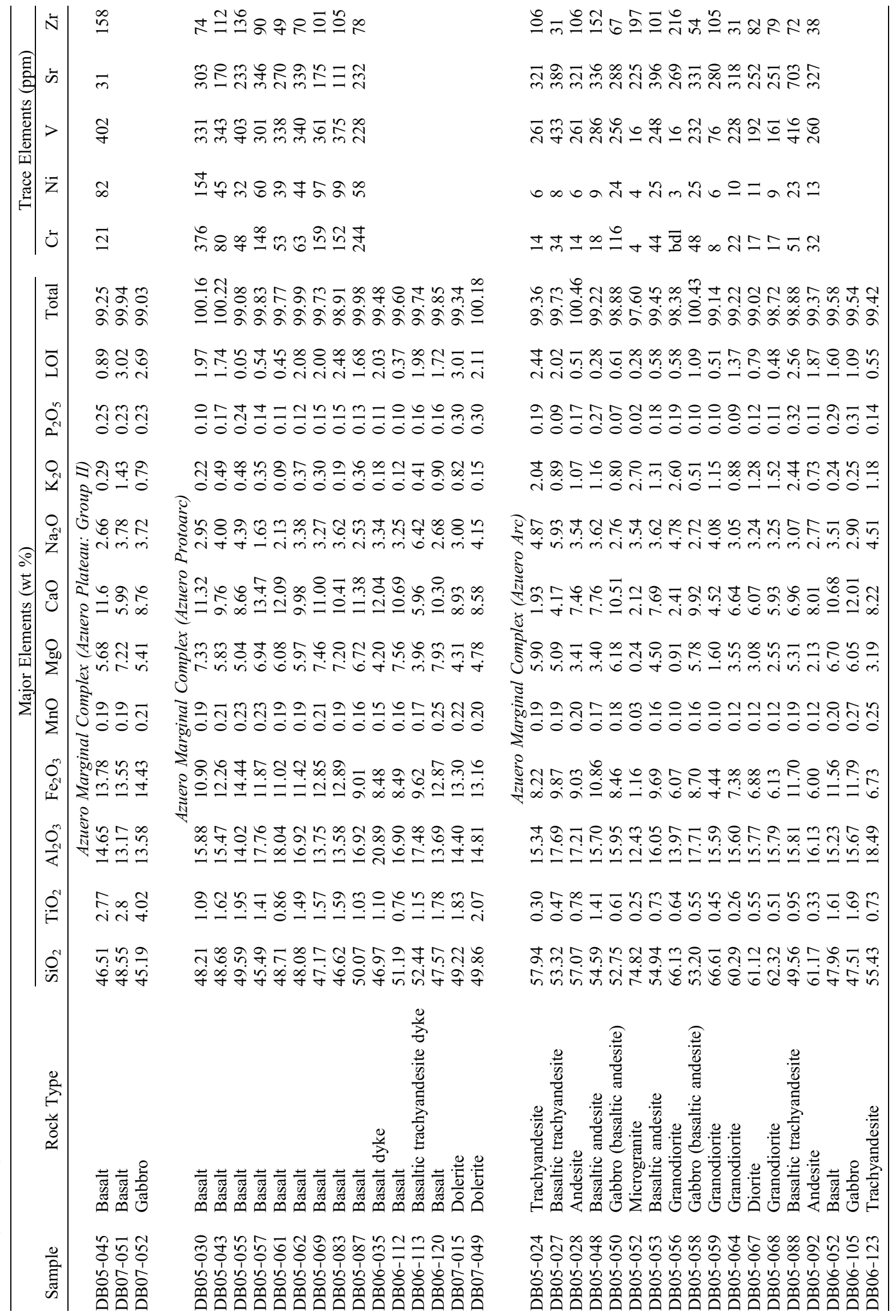




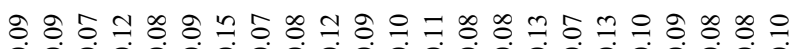

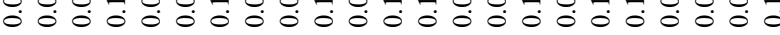

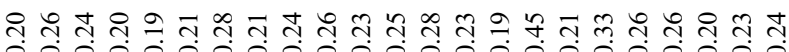

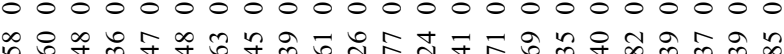

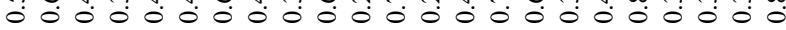

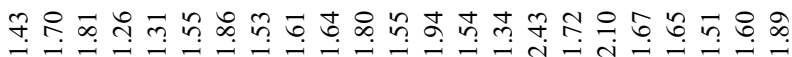

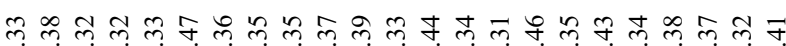

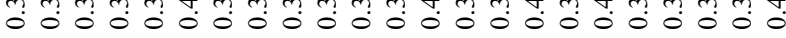

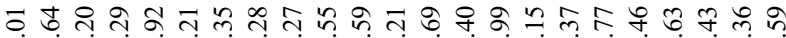
तi $\mathrm{i}$ त m

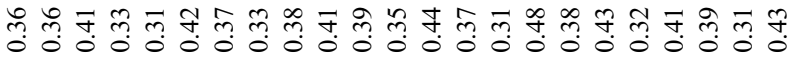
ก녀ำ त i 4 त

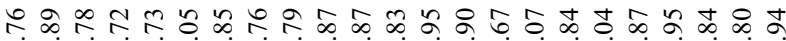

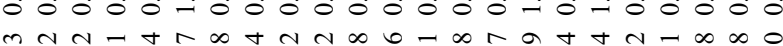
๓

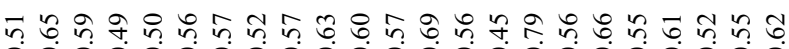

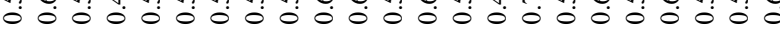

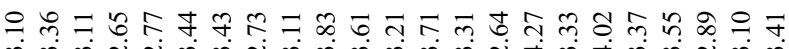

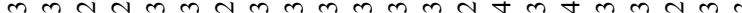
๖ ๖ ำ สิ $\approx$ 거 तु

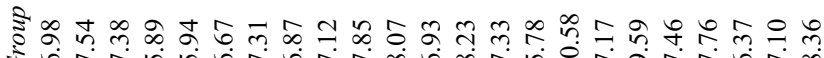
U)

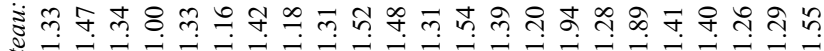
๙

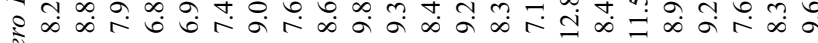

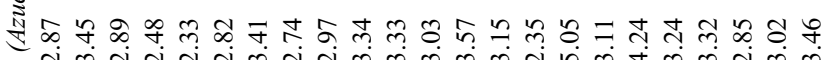
苛士

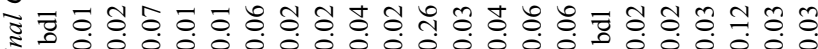

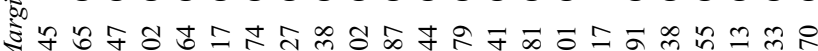

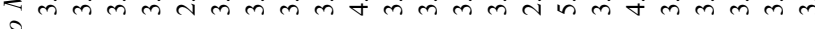
氕 भi

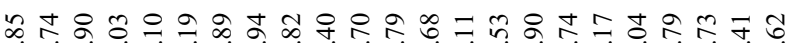
तิ่ 들

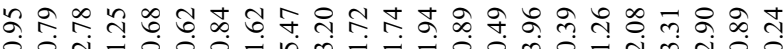
0 on

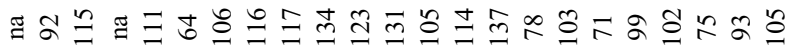

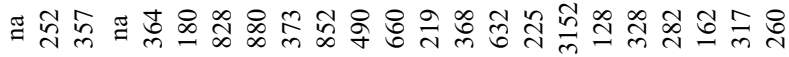

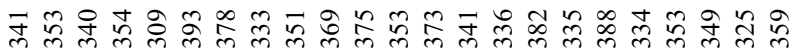

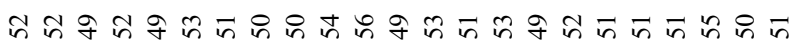

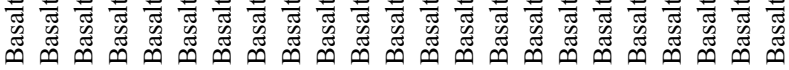

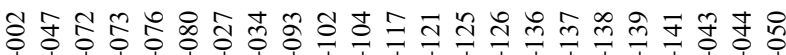

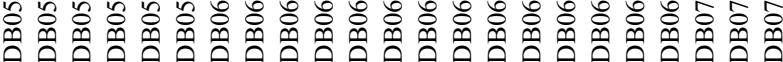




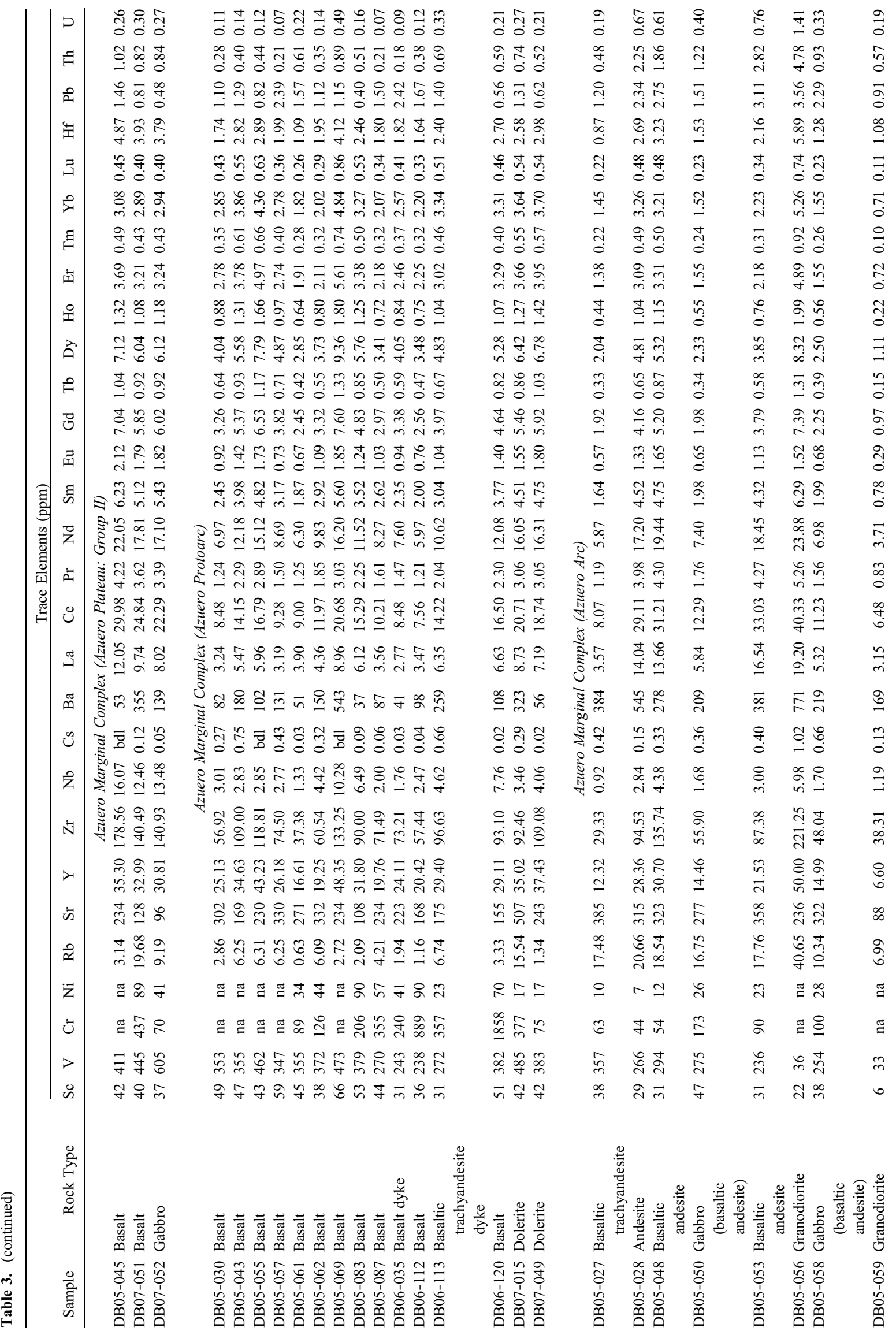


instrument equipped with a $193 \mathrm{~nm}$ ArF excimer laser (Lambda Physik, Germany) interfaced to an ELAN 6100 DRC quadrupole ICP-MS (Perkin Elmer, Canada. Operating conditions of the laser included a $170 \mathrm{~mJ}$ output energy, $10 \mathrm{~Hz}$ repetition rate, and $120 \mu \mathrm{m}$ ablation pit size. Helium was used as a cell gas. Dwell time per isotope ranged from 10 to $20 \mathrm{~ms}$; peak hopping mode was employed. An SRM 612 glass from NIST was used as an external standard. Three ablations per tetraborate glass bead were made to obtain the trace element contents. A list and field location of the analyzed samples are given in Table 1. Major, minor, and trace element contents are presented in Tables 2 and 3. More analytical procedure details are given in Appendix A.

\section{Results}

\subsection{Revised Tectonostratigraphy of Southern Costa Rica and Western Panama}

[13] We subdivided basement rocks outcropping in the fore arc between southern Costa Rica and western Panama into (1) the Golfito Complex, (2) the Inner Osa Igneous Complex, (3) the Outer Osa Igneous Complex, (4) the Osa Mélange, (5) the Azuero Accretionary Complex, and (6) the Azuero Marginal Complex (Figures 2 and 3). We focus here on summary descriptions of the Golfito Complex and Azuero Marginal Complex that provide an insight into arc initiation. Other igneous complexes of the area are also briefly described to clarify dissimilarities with the Azuero and Golfito complexes. Full tectonostratigraphic details of these complexes and development of the south Costa Rican and western Panamanian margins subsequently to subduction initiation are provided by Buchs et al. [2009] and in a forthcoming paper.

\subsubsection{Inner Osa Igneous Complex}

[14] The Inner Osa Igneous Complex is exposed in the Osa and Burica peninsulas (south Costa Rica, Figure 2). It is composed of Coniacian-Santonian (89.3 to $83.5 \mathrm{Ma}$ ) sequences of an oceanic plateau [Buchs et al., 2009] (Figure 3). This complex was formerly interpreted as an exposure of the CLIP [Hauff et al., 2000]. Our new tectonostratigraphic data suggest the Inner Osa Igneous Complex originated in the Pacific before being accreted to the CLIP margin in the Paleocene [Buchs et al., 2009]. Protoarc dykes have not been encountered in the Inner Osa Igneous Complex, whereas they occur in an autochtonous oceanic plateau part of 


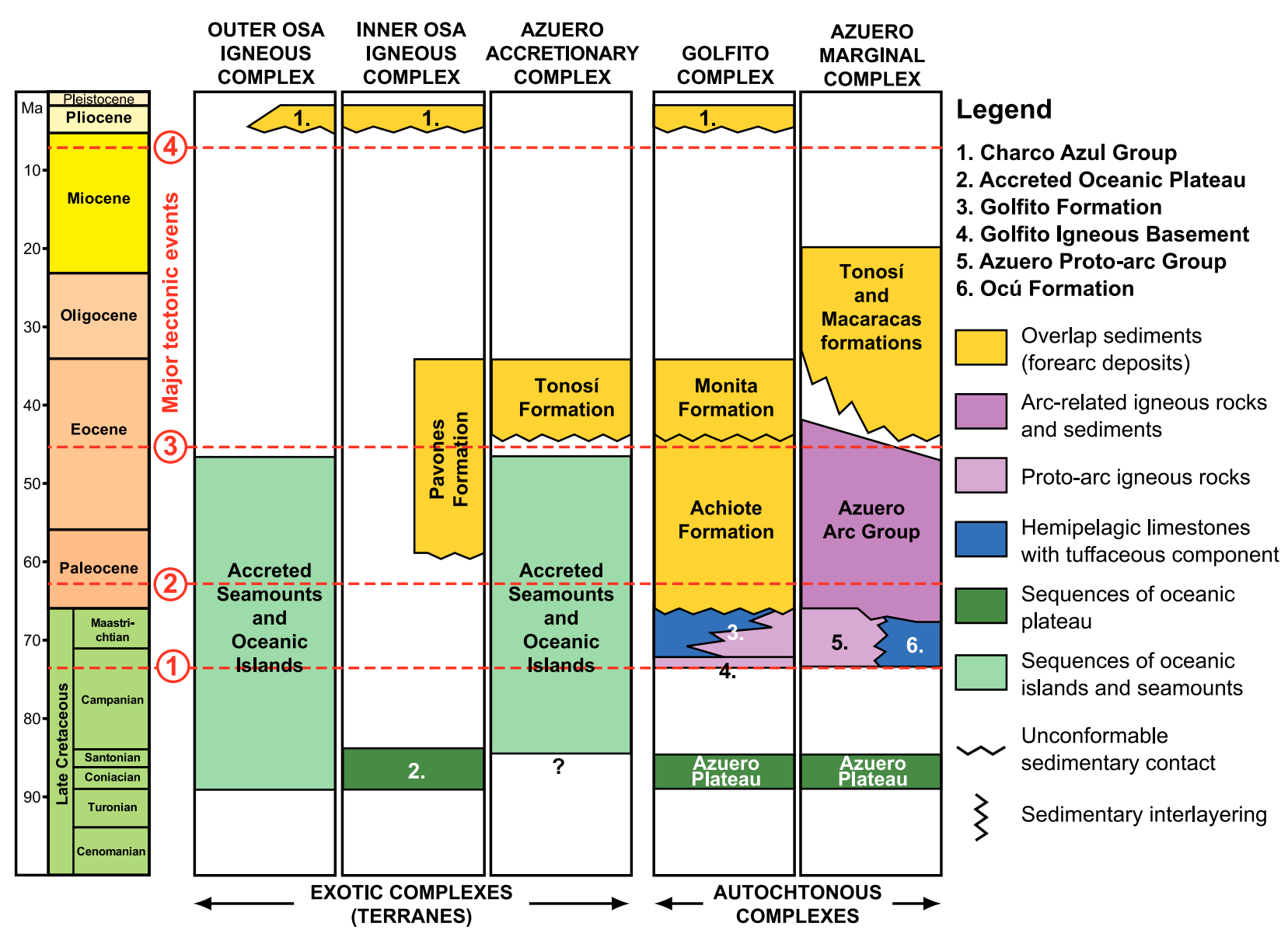

Figure 3. Synthetic tectonostratigraphic chart showing the igneous complexes exposed along the south Costa Ricanwest Panamanian fore arc. Details on the nature of the units are given by Buchs et al. [2009] and by D. M. Buchs et al. (Late Cretaceous to Miocene tectono-stratigraphy of the Azuero area (west Panama) and the discontinuous accretion and subduction erosion along the Mid-American Margin, submitted to Tectonophysics, 2010). A summary of the new tectonostratigraphy is provided in section 5.1. Major tectonic events recorded in the stratigraphy are (1) arc initiation in south Central America, (2) possible accretion of the Inner Osa Igneous Complex, (3) retreat of the arc front and subsequent accretion of the bulk of the Azuero Accretionary Complex in western Panama and accretion of the bulk of the Outer Osa Igneous Complex in southern Costa Rica, and (4) arrival of the Cocos Ridge at the subduction zone.

the Azuero Marginal Complex (i.e., the "Azuero Plateau," see below).

\subsubsection{Outer Osa Igneous Complex}

[15] The Outer Osa Igneous Complex is exposed in the outer part of the Osa Peninsula (Figure 2). It comprises several imbricate units consisting of Campanian to Eocene fragments of seamounts and oceanic islands, emplaced along the margin between the Paleocene and middle Eocene (Figure 3) [Buchs et al., 2009].

\subsubsection{Azuero Accretionary Complex}

[16] The Azuero Accretionary Complex forms the SW edge of the Azuero Peninsula (Figures 2 and 4).
It represents an accretionary complex composed of Cretaceous to Eocene accreted seamounts and oceanic islands [Hoernle et al., 2002; Lissinna, 2005; Hoernle and Hauff, 2007; Buchs, 2008] (Figure 3). The suture between the Azuero Accretionary Complex and arc sequences of the Azuero Marginal Complex (i.e., the "Azuero Arc Group," see below) coincides with a $\sim 2 \mathrm{~km}$ thick tectonic mélange shown as the "Azuero Mélange" in Figure 4.

\subsubsection{Golfito Complex}

[17] The Golfito Complex exposed in southern Costa Rica is separated by fault zones from the Inner Osa Igneous Complex in the SW and the Paleogene Fila Costeña Thrust Belt in the NE [Di Marco, 1994; Mende and Astorga, 2007; Morell 


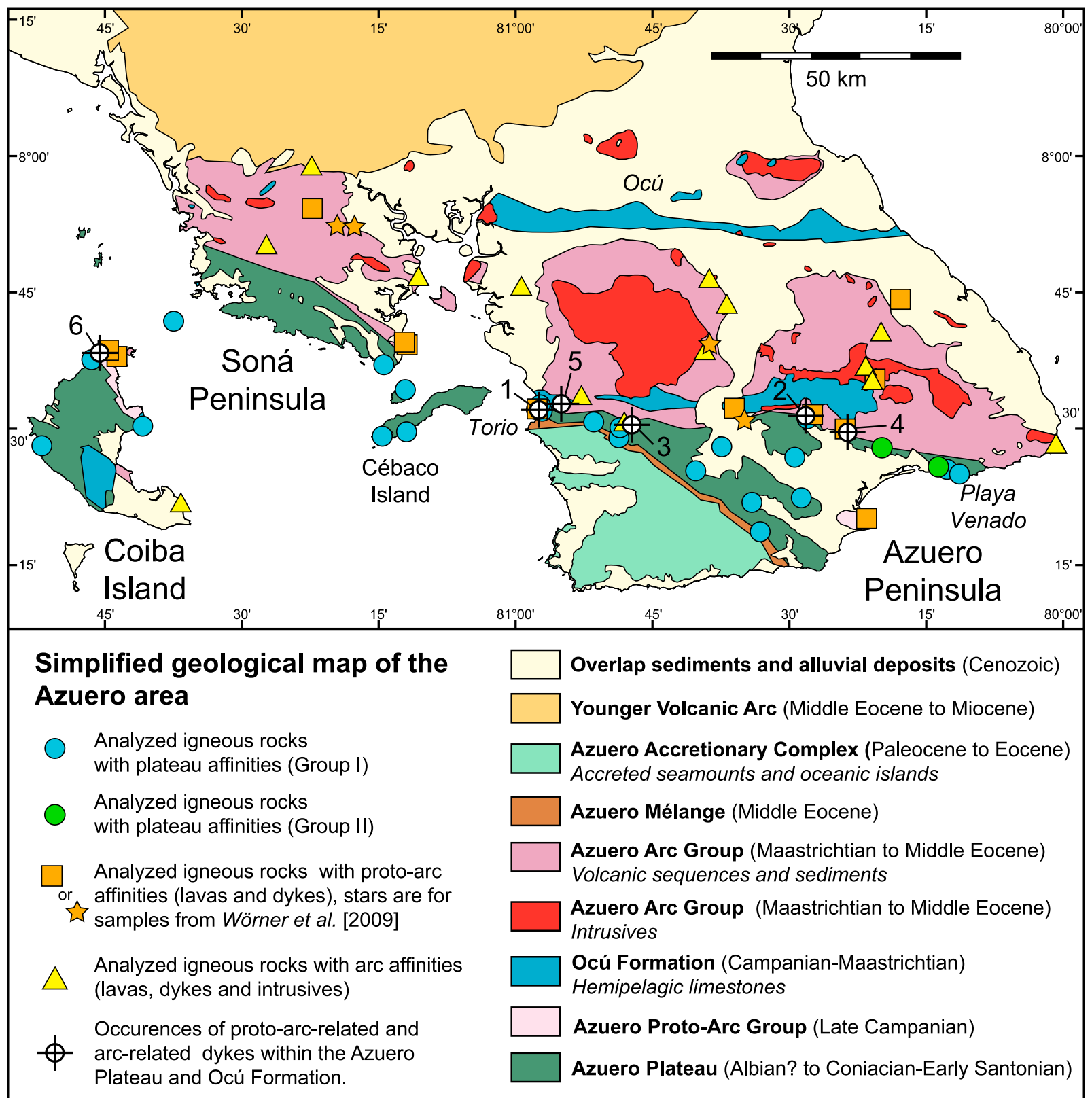

Figure 4. Simplified geological map of the Azuero Marginal Complex (modified after Dirección General de Recursos Minerales [1991]). Numbers 1-4 show occurrences of protoarc- and arc-related dykes encountered in the Azuero Plateau: 1 indicates Torio (504495/832730, Plate 1b), 2 indicates Río Joaquín (560250/831725, Plate 1c), 3 indicates Río Quebro (522705/830475), and 4 occurs along the road between Tonosí and La Miel (567460/829260) (UTM WGS84 coordinates). Numbers 5 and 6 show occurrences of protoarc- and arc-related dykes found in the Ocú Formation: 5 indicates Rio Torio $(\sim 507610 / 834635)$ and 6 indicates NW Coiba Island (415710/844800) (UTM WGS84 coordinates).

et al., 2008; Buchs, 2008] (Figure 2). The Golfito Complex is composed of a sequence of Late Cretaceous to Paleogene volcanic rocks, hemipelagic sediments, and volcano-sedimentary deposits [Dengo, 1962; Schmidt-Effing, 1979; Obando, 1986; Di Marco, 1994; Di Marco et al., 1995]. We follow here the stratigraphic subdivision of Di Marco et al. [1995] wherein three tectonostratigraphic units are defined: (1) an Igneous Basement, pre-late Campanian or late Campanian lava flows; (2) the Golfito Formation, a volcano-sedimentary sequence of interlayered lava flows and late Campanian to 

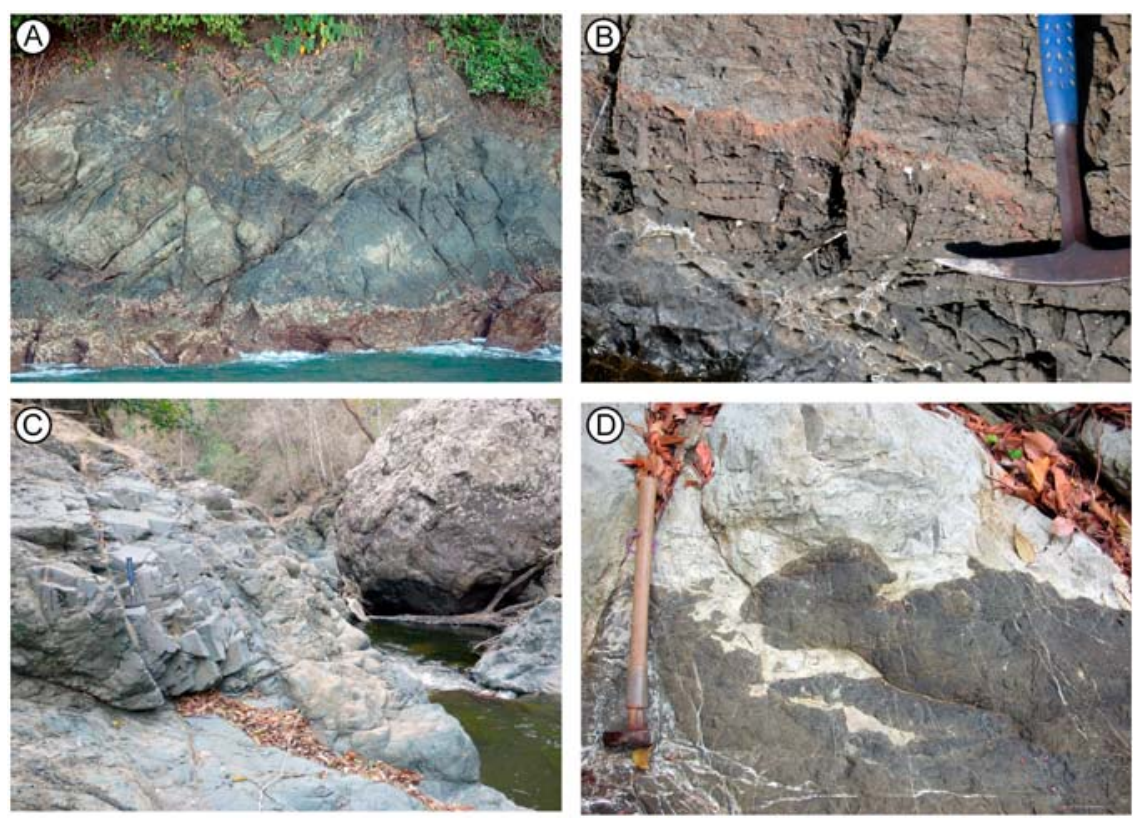

Figure 5. Outcrops showing typical stratigraphic relationships used in our study to constrain the earliest development of the south Central American Arc. (a) interlayered Campanian-Maastrichtian hemipelagic limestones and protoarc igneous rocks of the Golfito Formation, both crosscut by a dyke of protoarc igneous rock (Punta Curupacha, Costa Rican coordinates 549.5/287.3). (b) Exposure of the Azuero Plateau (top) in contact with a dyke of protoarc basalt exhibiting porphyritic texture and clear chilled margin (bottom) (Torio, 504495/832730, UTM WGS84 (location indicated by 1 in Figure 4)). (c) Dyke of a protoarc basalt within the Azuero Plateau, in the vicinity of the Azuero Arc group (Río Joaquín, 560250/831725, UTM WGS84 (location indicated by 2 in Figure 4)). (d) Soft deformation of late Campanian ( $\sim 75-73 \mathrm{Ma}$ ) hemipelagic limestones intruded by a dyke of protoarc igneous rock (NW Coiba Island, 415710/844800, UTM WGS84 (location indicated by 3 in Figure 4)).

middle Maastrichtian ( 75-66 Ma) tuffaceous hemipelagic limestones, resting on the Igneous Basement; and (3) the Achiote Formation, a middle Maastrichtian to Paleocene volcaniclastic-tuffitic sequence, containing material related to a nearby silicic volcanism, deposited on top of the Golfito Formation (Figure 3). Although recent tectonics has disturbed the arrangement of these units, they have been considered by several authors to form a continuous sequence from the Late Cretaceous to the Paleocene [Obando, 1986; Di Marco, 1994; Di Marco et al., 1995; Mende, 2001].

[18] Some Golfito Formation sediments were deposited concurrently in the late Campanian-middle Maastrichtian with emplacement of basaltic lava flows [Obando, 1986; Di Marco, 1994; Buchs, 2008]. Hemipelagic limestones also occur as xenoliths embedded within the lavas flows and the sequence is crosscut by volcanic dykes (Figure 5a). The hemipelagic limestones locally contain a tuffaceous component and primary quartz grains that probably relates to an intermediate-silicic volcanism distinct from the Golfito Complex [Mende, 2001;
Buchs, 2008]. These limestones exhibit strong similarities with the Campanian-Maastrichtian hemipelagic limestones in the area of the Río Changuinola [Fisher and Pessagno, 1965; Mende, 2001].

[19] Paleomagnetic data for limestone exposures of the Golfito Formation indicate the Golfito Complex formed at $\sim 5^{\circ} \mathrm{N}$ [Frisch et al., 1992; Di Marco et al., 1995]. At most, the complex has subsequently moved $\sim 4^{\circ}$ degrees further north. This is unlike other plateau-like igneous complexes of Costa Rica, such as the Nicoya and Inner Osa Igneous complex, which formed in the Southern Hemisphere between $\sim 6^{\circ} \mathrm{S}$ and $\sim 17^{\circ} \mathrm{S}$ [Di Marco et al., 1995].

[20] The lavas from the Golfito Complex include basalt, basaltic andesite, basaltic trachyandesite, and trachyandesite [Di Marco, 1994; Hauff et al., 2000]. An oceanic plateau affinity has been inferred from trace element abundance systematics and radiogenic isotopes of three samples, suggesting an association of the complex with the CLIP [Hauff et al., 2000; Hoernle and Hauff, 2007]. We show below that the igneous rocks from Golfito have 
major and trace element compositions ranging from those for plateau-like to more arc-like compositions.

\subsubsection{Azuero Marginal Complex}

[21] The Azuero Marginal Complex is defined here as the area encompassing the Coiba Island, Soná Peninsula, and Azuero Peninsula, with exception of the SW corner of the Azuero Peninsula that comprises the Azuero Accretionary Complex (Figures 2 and 4). This area is generally regarded as an assemblage of CLIP exposures, accreted ocean islands, and arc-related sequences [e.g., Denyer et al., 2006; Hoernle and Hauff, 2007]. We subdivided it into four mappable lithostratigraphic units: (1) the Azuero Plateau, (2) the Ocú Formation, (3) the Azuero Protoarc Group, and (4) the Azuero Arc Group (Figures 3 and 4). The units are locally capped by Eocene and younger overlap sequences.

[22] The Azuero Plateau is dominated by massive and pillowed lava flows of plateau-like affinities (i.e., flat patterns on primitive mantle-normalized multielementary and chondrite-normalized rare earth element diagrams) [Lissinna, 2005; Wörner et $a l ., 2009]$, with scarce occurrences of interbedded radiolarite [Kolarsky et al., 1995] (Figure 3). The age of the Plateau is Coniacian-early Santonian $(\sim 89-85 \mathrm{Ma})$ on the basis of radiolarite ages [Kolarsky et al., 1995; Buchs et al., 2009], in broad agreement with ${ }^{40} \mathrm{Ar} /{ }^{39} \mathrm{Ar}$ incremental heating ages for low-K, tholeiitic basalts $(93.5 \pm 5.3$ to $82.6 \pm$ $3.2 \mathrm{Ma}$ [Lissinna, 2005]. A low-K tholeiitic basalt from Soná Peninsula gave a $71.3 \pm 2.1 \mathrm{Ma}$ matrix total fusion age [Hoernle et al., 2002]. A K/Ar date of $\sim 98 \mathrm{Ma}$ has been obtained for a basalt south of the Azuero Peninsula (Playa Venado) [Bourgois et al., 1982]. Dykes of the Azuero Protoarc and Azuero Arc groups crosscut the Plateau at several sites (Figures 4, 5b, and 5c).

[23] The Ocú Formation is composed of foraminifera-bearing, Campanian-Maastrichtian hemipelagic limestones [del Giudice and Recchi, 1969; Tournon et al., 1989]. The formation probably rests upon the Azuero Plateau (Figure 4). Paleomagnetic data indicate the Ocú Formation formed at $\sim 2^{\circ} \mathrm{N}$, at paleolatitudes similar to the Golfito Complex and SW Caribbean Plate (Colombian Basin) [Di Marco et al., 1995; Acton et al., 2000]. Foraminifera of two limestones samples from the Ocú type locality (525844/873241, UTM WGS84) provide a Campanian age for the formation (see Appendix B, with comments and illustrations). The Ocú Formation limestones, similar to limestones of the same age in the Golfito Formation and sediments outcropping in the Río Changuinola area, locally contain a tuffaceous component and volcanic clasts derived from an intermediate-silicic volcanic source [ $\mathrm{del}$ Giudice and Recchi, 1969] (see also Appendix C). The Ocú Formation locally contain fragments of larger benthic foraminifera [del Giudice and Recchi, 1969] (see also Appendix C), which are evidence for nearby shallow water environments. Locally the Ocú Formation contains interbeds of basaltic lava flows and is crosscut by basaltic dykes of the Azuero Protoarc Group [del Giudice and Recchi, 1969; Tournon, 1984] (Figure 4). A hemipelagic limestone of the Ocú Formation in NW Coiba Island (location indicated by 6 in Figure 4 and Figure 5d) is intruded by a mafic dyke of the Azuero Protoarc Group (415710/844800, UTM WGS84). We have dated the limestone, which shows synvolcanic soft deformation, as late Campanian ( 75-73 Ma) (Appendix B); we conclude this also corresponds to the age of emplacement of the Azuero Protoarc Group.

[24] The Azuero Protoarc Group occurs as mafic dykes crosscutting the Azuero Plateau and Ocú Formation in the vicinity of the Azuero Arc Group, and mafic lava flows, locally interbedded with hemipelagic limestones of the Ocú Formation (Figures 4 and 5b-5d).

[25] The Azuero Arc Group is exposed in the central and northern Azuero Marginal Complex (Figures 2 and 4). It is dominantly intermediate to silicic lavas and related intrusives [del Giudice and Recchi, 1969; Metti and Recchi, 1976; Kolarsky et al., 1995; Lissinna, 2005; Wörner et al., 2009; Wegner et al., 2010] (Figures 3 and 4). The igneous rocks have typical suprasubduction geochemical signatures (i.e., they are depleted in $\mathrm{Nb}$ and $\mathrm{Ti}$ relative to elements of similar peridotite-melt incompatibility, and enriched in mobile elements such as $\mathrm{Pb}$ and $\mathrm{Ba}$ ), and represent an extinct volcanic arc [Lissinna, 2005; Wörner et al., 2009; Wegner et al., 2010]. The intermediate to differentiated igneous rocks are locally stratigraphically associated with volcanic, calcareous and tuffaceous sediments [del Giudice and Recchi, 1969]. A K/Ar age of $69 \pm 10 \mathrm{Ma}$ was obtained for a quartz diorite from La Pitalosa (Azuero) [ $\mathrm{del}$ Giudice and Recchi, 1969]. ${ }^{40} \mathrm{Ar} /{ }^{39} \mathrm{Ar}$ ages of the igneous arc rocks range from $\sim 66$ to $40 \mathrm{Ma}$ [Lissinna, 2005; Wegner et al., 2010]. An age trend is observed throughout the Azuero Marginal Complex and western Panamean Isthmus, with youngest ${ }^{40} \mathrm{Ar} /{ }^{39} \mathrm{Ar}$ ages in the north and oldest 


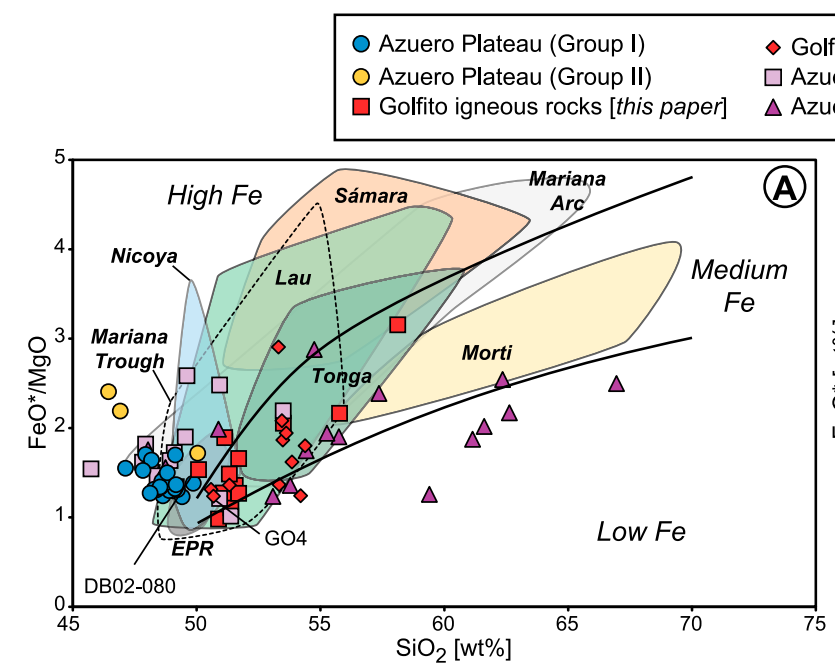

$\diamond$ Golfito igneous rocks [Di Marco, 1994; Hauff et al.. 2000] Azuero Proto-arc Group
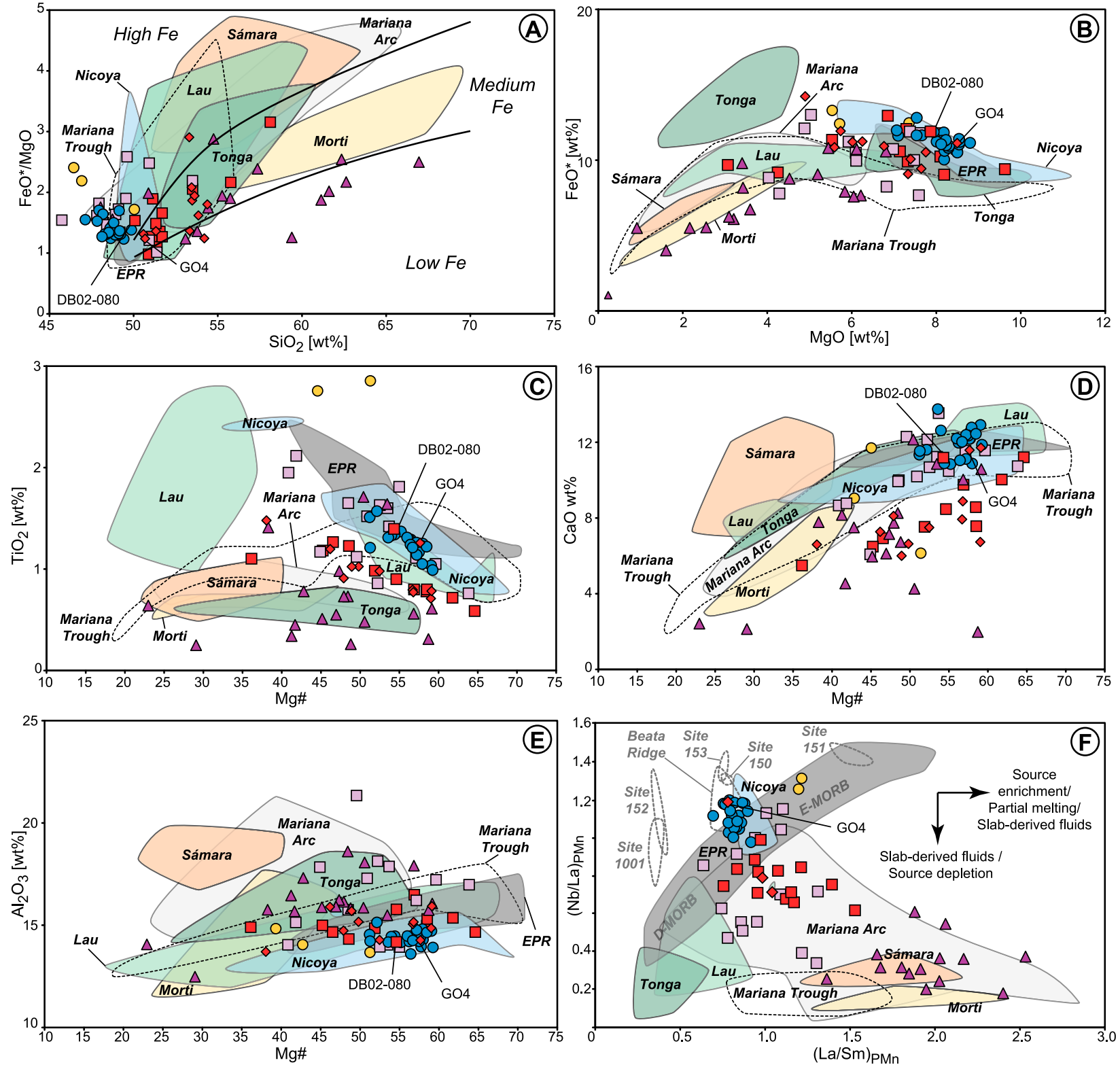

Figure 6. Geochemical characteristics of the igneous rocks of the Golfito Complex and Azuero Marginal Complex, with comparison to the "Sámara Arc" [Patino et al., 2004], "Morti Arc" [Maury et al., 1995], East Pacific Rise MORBs (EPR) [Su and Langmuir, 2003], Nicoya Complex (oceanic plateau) [Hauff et al., 2000], Tonga Arc [Turner and Hawkesworth, 1997], Lau Basin [Turner and Hawkesworth, 1997], Mariana Arc and Trough (GEOROC online database), and CLIP basalts from the Caribbean Sea (locations in Figure 1) [Sinton et al., 1998; Révillon et al., 2000; Kerr et al., 2002, 2009]. (a) $\mathrm{FeO}^{*}-\mathrm{SiO}_{2}$ diagram after Arculus [2003]. (c-e) $\mathrm{Mg} \#=100 \times \mathrm{mol}[\mathrm{MgO}] /(\mathrm{mol}[\mathrm{MgO}]+$ mol [FeO*]). (f) Primitive mantle after McDonough and Sun [1995]. Analyses were plotted on an anhydrous basis for Figures 6a-6e.

ages in the south. On the basis of these ages, it has been proposed a progressive shift of the volcanic front toward the Caribbean Plate occurred during the Cenozoic, possibly as a response to subduction erosion and/or slab flattening [Lissinna et al., 2002]. That migration has resulted in good exposure of the oldest South Central American Volcanic Arc in western Panama. 

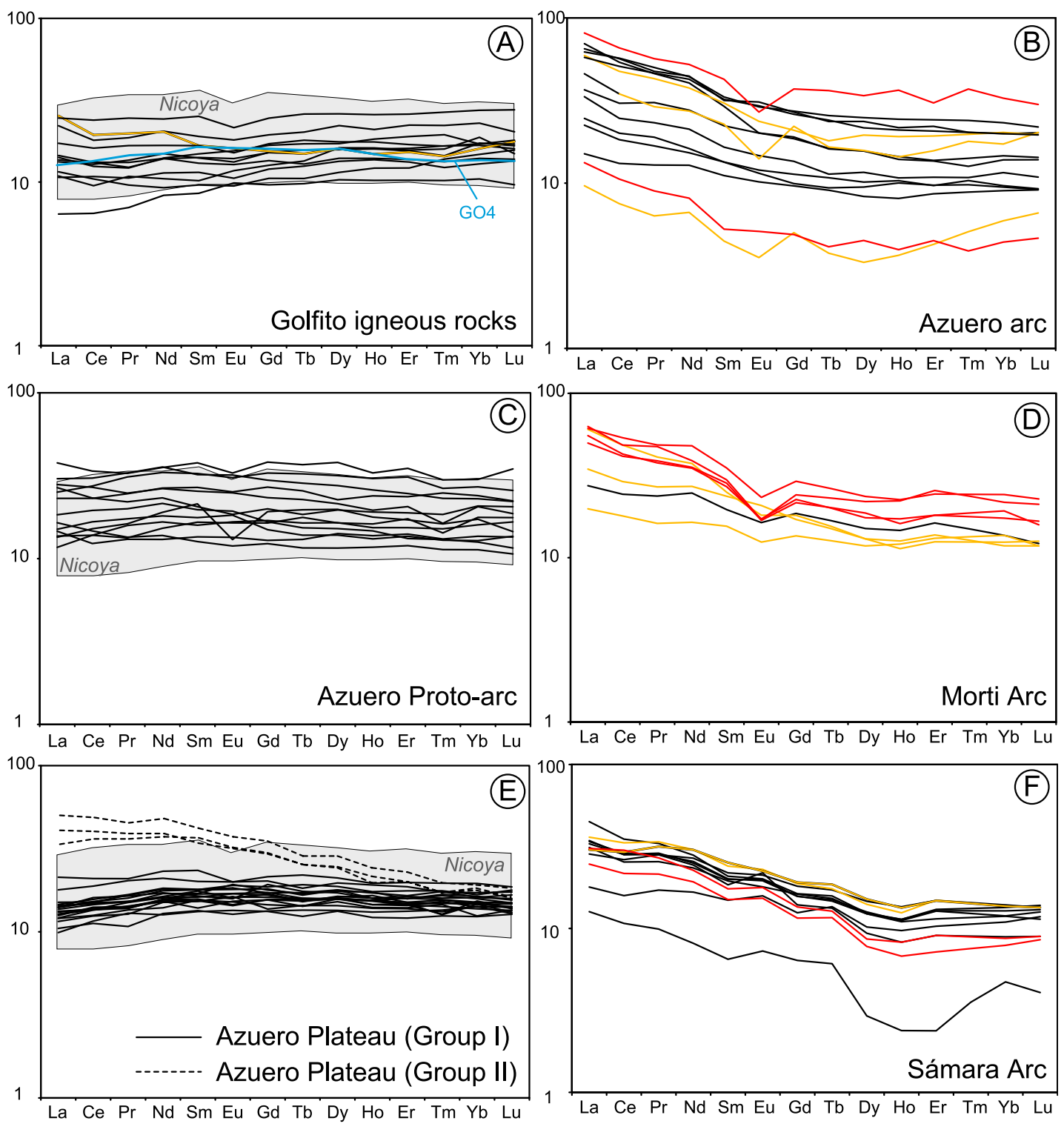

$$
-\mathrm{SiO}_{2}<57 \%
$$

$\mathrm{SiO}_{2}=57-63 \%$

$\mathrm{SiO}_{2}>63 \%$

Figure 7. Chondrite-normalized REE diagrams. Chondrite abundances from McDonough and Sun [1995]. Sámara Arc after Patino et al. [2004], Morti Arc after Maury et al. [1995], and Nicoya Complex after Hauff et al. [2000].

\subsection{Igneous Rocks of the Golfito Complex and Azuero Marginal Complex}

[26] We describe here the igneous rocks forming parts of the Golfito Complex and Azuero Marginal Complex. New geochemical data for the Golfito Complex are integrated with previous data by $D i$ Marco [1994] and Hauff et al. [2000] to illustrate geochemical similarities and/or differences between igneous rocks from the Golfito Complex, Azuero Plateau, Azuero Protoarc Group, and Azuero Arc Group. Igneous rocks from distinct origins are also used for comparison (Figures 6-8). The Tonga Arc,
Lau Basin, and Mariana Arc and Trough are used as compositional end-members of Pacific intraoceanic volcanic arcs and related back-arc basins. Although the CLIP and oceanic plateaus in general exhibit a large compositional variability with both enriched and depleted signatures [e.g., Petterson et al., 1999; Kerr et al., 2009], we use here a restricted, consistent geochemical data set from the Nicoya Complex after Hauff et al. [2000] as a proxy for plateau-like affinities observed in the bulk of an oceanic plateau. This approach is motivated by several reasons: (1) oceanic LIPs are predominantly composed by igneous rocks with plateau-like 

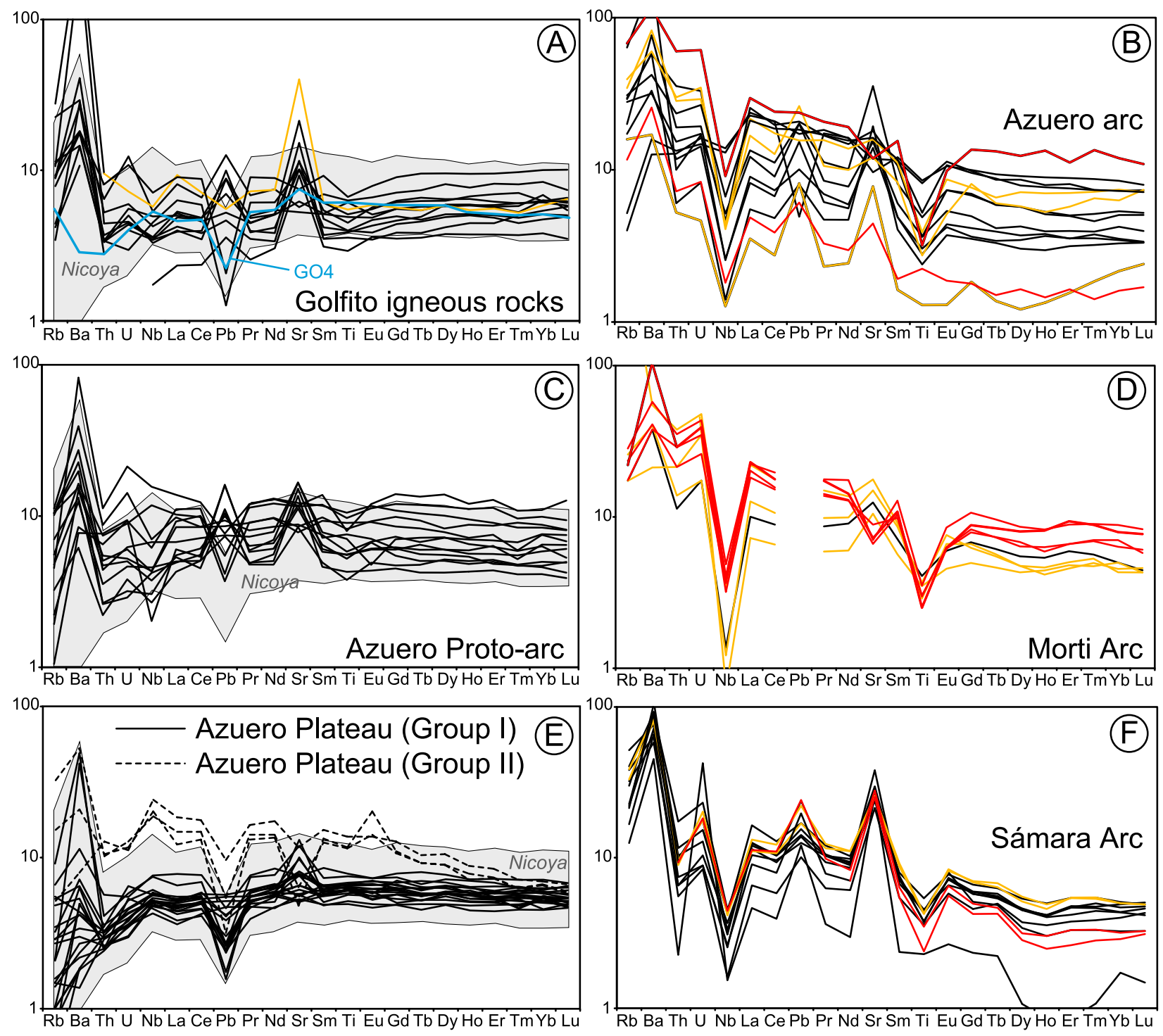

$$
\mathrm{SiO}_{2}<57 \%
$$

$\mathrm{SiO}_{2}=57-63 \%$

$\mathrm{SiO}_{2}>63 \%$

Figure 8. Primitive mantle-normalized multielement diagrams. Primitive mantle from McDonough and Sun [1995]. Sámara Arc after Patino et al. [2004], Morti Arc after Maury et al. [1995], and Nicoya Complex after Hauff et al. [2000].

affinities [Kerr, 2003], (2) some circum-Caribbean igneous complexes interpreted to be part of the CLIP have a controversial origin and may pertain to distinct oceanic plateaus [e.g., Kerr, 2005; Baumgartner et al., 2008], and (3) high compositional variability of CLIP basalts recovered by drilling and dredging in the Caribbean Sea is observed at a scale much larger than that of the Azuero Marginal Complex and is not observed at individual sites [Sinton et al., 1998; Révillon et al., 2000; Kerr et al., 2002, 2009] (see also ODP and IODP sites in Figures 1 and 6).

\subsubsection{Golfito Complex}

[27] Volcanic rocks ranging from basalt to trachyandesite occur as massive to thin pillowed lava flows. The mineral assemblages are subhedral plagioclase, euhedral clinopyroxene, and Fe-Ti oxides. Olivine has not been observed. Some pillow lavas have a porphyritic texture with clinopyroxene phenocrysts. Spherical vesicles $(<3 \mathrm{~mm})$ filled with calcite, zeolites and/or chlorite are locally present. A pervasive low- $T$ alteration affected igneous rocks of the complex. Interstitial glass in the lavas 
has been replaced by palagonite and chlorite, all the plagioclase is argillitized, and much clinopyroxene is chloritized. In a few samples, euhedral secondary quartz minerals are found in interstitial glass and in close proximity to granophyres. These samples display anomalously high silica content that is related to silica enrichment by fluid flows or assimilation of silica-rich melts/rocks by basaltic magma (Figure 5a).

[28] The lavas of the Golfito Complex define a medium-Fe series, distinct from that of typical oceanic plateaus such as the Nicoya Complex (Figures 6a and 6b). The Golfito Complex has also lower $\mathrm{CaO}$ and $\mathrm{TiO}_{2}$ at a given $\mathrm{Mg} \#(\mathrm{Mg} \#=100 \times$ $\mathrm{mol}[\mathrm{MgO}] /\left(\mathrm{mol}[\mathrm{MgO}]+\mathrm{mol}\left[\mathrm{FeO}^{*}(\mathrm{Fe}\right.\right.$ total expressed as $\mathrm{FeO})]$ )) than the Nicoya Complex (Figures 6c and 6d). Rare earth element (REE) abundance systematics of the Golfito Complex have plateau-like affinities broadly similar to the Nicoya Complex (Figure 7a). On some primitive mantle (PM)-normalized multielement diagrams (Figure $8 \mathrm{a}$ ), $\mathrm{Rb}, \mathrm{Ba}, \mathrm{U}, \mathrm{Pb}$, and $\mathrm{Sr}$ contents show large variations between the lavas, indicating a possible remobilization of these mobile elements during alteration. Ti contents are generally low and form negative anomalies on the multielement patterns, which are not observed in the Nicoya Complex. Similarly, negative $\mathrm{Eu}$ anomalies are observed for some samples of the Golfito Complex.

[29] Variations of incompatible immobile elements are best illustrated on a $(\mathrm{Nb} / \mathrm{La})_{\mathrm{PMn}}-(\mathrm{La} / \mathrm{Sm})_{\mathrm{PMn}}$ diagram (Figure 6f), which highlights slab-derived fluid enrichments, mantle wedge source fertility, and/or various degrees of partial melting. On such a diagram, the Golfito Complex data are bracketed by the fields of plateau-like igneous rocks (e.g., Nicoya Complex and Azuero Plateau) and Paleogene arc-related igneous rocks from the Azuero Peninsula. Similarly, in $\mathrm{MgO} / \mathrm{FeO}^{*}{ }_{-} \mathrm{SiO}_{2}, \mathrm{FeO}^{*}-$ $\mathrm{MgO}$ and $\mathrm{TiO}_{2}-\mathrm{Mg}$ \# diagrams, the Golfito Complex is located between trends for the plateau suites and Azuero Arc (Figure 6). Note basaltic sample DB02-080 (this study) and GO4 of Hauff et al. [2000] resembles igneous rocks of the Azuero Plateau, with notably higher $(\mathrm{Nb} / \mathrm{La})_{\mathrm{PMn}}$ and lower $(\mathrm{La} / \mathrm{Sm})_{\mathrm{PMn}}$ (Figure 6f) and higher $\mathrm{TiO}_{2}$ at a given $\mathrm{Mg} \#$ (Figures 6c, 7, and 8). Location and discussion of the origin of these samples are given below.

\subsubsection{Azuero Plateau}

[30] Volcanic rocks of the Azuero Plateau are sheet flows and pillow basalts. Rare gabbroic intrusives have been found in the area of Playa Venado. Textures of the lavas are ophitic to intersertal, with ubiquitous plagioclase, clinopyroxene, opaque minerals and glass, and minor olivine in some flows. The degree of alteration of the lava is minor compared to the volcanic rocks of the Golfito Complex. With the exception of olivine that is replaced by chlorite and serpentine, minerals are well preserved. Small clinopyroxene and/or plagioclase phenocrysts are rare.

[31] The Azuero Plateau includes 2 geochemical groups (Group I and II). Group I forms the bulk of the igneous rocks of the Azuero Plateau, whereas Group II is restricted to some lava flows and gabbros NW of Playa Venado (Figure 4). Group I has a composition very similar to the Nicoya Complex (Figures 6, 7e, and 8e) with a high-Fe (tholeiitic) differentiation trend (Figures $6 a$ and $6 b$ ). Group II has also a tholeiitic affinity, but major element contents are distinct from those of Group I, with lower $\mathrm{SiO}_{2}, \mathrm{Mg} \#$ and $\mathrm{CaO}$, and higher $\mathrm{TiO}_{2}$ contents in Group II. Trace element contents of Group I display typical plateau-like affinities, whereas Group II has a more enriched character (Figures 7e and 8e). A gabbro sample from Group II has unusually high $\mathrm{Ti}$ and $\mathrm{Nb}$ contents probably related to accumulation of a $\mathrm{Ti}-\mathrm{Nb}$-rich mineral phase. In both groups variations in $\mathrm{Rb}, \mathrm{Ba}, \mathrm{Pb}$ and $\mathrm{Sr}$ contents are observed and result from low- $\mathrm{T}$ alteration. $(\mathrm{Nb} / \mathrm{La})_{\mathrm{PMn}^{-}}-(\mathrm{La} / \mathrm{Sm})_{\mathrm{PMn}}$ variations of Group I are similar to the Nicoya Complex, whereas those of Group II have an enriched character intermediate between Group I and basalts from ODP Site 151 (Figure 6f). Igneous rocks from Group I have lower $(\mathrm{Nb} / \mathrm{La})_{\mathrm{PMn}}$ and higher $(\mathrm{La} / \mathrm{Sm})_{\mathrm{PMn}}$ than those from the Golfito Complex (with exception of sample GO4) and the Azuero Protoarc Group. Igneous rocks from Group II have higher $(\mathrm{Nb} / \mathrm{La})_{\mathrm{PMn}}$ and $(\mathrm{La} / \mathrm{Sm})_{\mathrm{PMn}}$ than those from the Golfito Complex and the Azuero Protoarc Group.

\subsubsection{Azuero Protoarc Group}

[32] Igneous rocks of the Azuero Protoarc Group consist of basaltic to basaltic trachyandesitic lava flows and dykes. Their texture and mineralogy exhibit a large variability, with subophitic, intersertal and porphyritic textures. The igneous rocks contain clinopyroxene, plagioclase, opaque mineral, orthopyroxene, amphibole, alkali-feldspar and glass. The phenocryst content ranges from $<1 \%$ to $\sim 45 \%$, and rocks are well preserved. 
[33] The Azuero Protoarc defines a high-Fe (tholeiitic) differentiation trend dissimilar to the Azuero Plateau, Golfito and Nicoya complexes (Figures 6a-6e). Incompatible element contents of the Azuero Protoarc are similar to the igneous rocks of the Golfito Complex on $(\mathrm{Nb} / \mathrm{La})_{\mathrm{PMn}}-(\mathrm{La} / \mathrm{Sm})_{\mathrm{PMn}}$, chondrite-normalized REE, and PM-normalized multielementary diagrams (Figures $6 \mathrm{~h}, 7$, and 8).

[34] Rocks classified here as "Azuero Protoarc Group" are similar in terms of geochemical composition to "enigmatic CLIP arc rocks" reported by Wörner et al. [2009] from the Chagres Igneous Complex (central Panama, Figure 2) and some samples from the "Soná-Azuero Arc" by Wegner et al. [2010], which includes both our Azuero Protoarc and Azuero Arc groups. In detail, samples similar to our "Protoarc Group" are classified by Wörner et al. [2009] and Wegner et al. [2010] either as "CLIP oceanic basement," "Early arc" or "CLIP arc." Other samples classified as "CLIP arc" by Wörner et al. [2009] are similar to our "Azuero Arc Group" (see below).

\subsubsection{Azuero Arc Group}

[35] The Azuero Arc Group comprises a large variety of volcanic rocks ranging in composition from basalt to dacite. Lava flows have been observed in association with large intrusive complexes and eroded lava domes. Large intrusives are generally associated with elevated topographic relief. In the central Azuero Marginal Complex, granodioritic intrusives cover large areas and are distributed along a well-defined NW-SE trend (Figure 4). Andesite aa flows are common. Well preserved volcanic morphologies tend to indicate younger volcanism occurred in the northern part of the Azuero Marginal Complex and possibly developed along rifted/faulted zones. Lavas have typical intergranular to porphyritic textures. Multiply zoned plagioclase, alkali feldspar, greenish clinopyroxene, amphibole, and quartz are typical phenocrysts in the porphyritic lavas. Intrusive complexes are formed by mafic and silicic igneous rocks. The differentiated intrusives frequently contain large amphibole and zircon.

[36] Major and minor element contents of igneous rocks of the Azuero Arc Group show affinities similar to low-Fe differentiation trends (Figures 6a-6e). In terms of major element contents, the igneous rocks of the Azuero Arc Group are similar to arc-related lavas from the Río Morti (eastern Panama). Arcrelated rocks from Punta Sámara (northern Costa Rica) also share some similarities with the Azuero
Arc Group in terms of $\mathrm{SiO}_{2}, \mathrm{TiO}_{2}, \mathrm{FeO}{ }^{*}, \mathrm{Na}_{2} \mathrm{O}$ and $\mathrm{K}_{2} \mathrm{O}$ contents. The "Sámara Arc" has on the other hand a globally lower $\mathrm{MgO}$ content and much higher $\mathrm{CaO}$ and $\mathrm{Al}_{2} \mathrm{O}_{3}$ contents at the same $\mathrm{Mg} \#$ (Figure 6). Trace element contents of the igneous rocks of the Azuero Arc Group are typical of island arcs with a progressive enrichment in most incompatible elements, negative $\mathrm{Nb}-\mathrm{Ti}$ anomalies and positive $\mathrm{Pb}$ anomalies on a $\mathrm{PM}$-normalized multielementary diagram (Figure $8 b$ ). Trace element contents of the igneous rocks of the Azuero Arc Group are similar to those of the Sámara and Morti arcs (Figures 7 and 8). On a $(\mathrm{Nb} / \mathrm{La})_{\mathrm{PMn}^{-}}$ $(\mathrm{La} / \mathrm{Sm})_{\mathrm{PMn}}$ diagram, igneous rocks of the Azuero Arc Group, Sámara Arc and Río Morti plot in the field of the Mariana Arc (i.e., a typical high-Fe medium-K arc suite), and distinct from the Tonga Arc (i.e., a typical high-Fe low-K arc suite) (Figure 6f).

\section{Origins of the Golfito Complex and Azuero Marginal Complex}

[37] New interpretations on the origins of the Golfito Complex and Azuero Marginal Complex are presented below based on integration of new and existing tectonostratigraphic and geochemical data.

\subsection{Origins of the Golfito Complex}

[38] The Golfito Complex is currently regarded as an uplifted sequence of an oceanic plateau [Hauff et $a l ., 2000]$. This interpretation is in disagreement with the stratigraphic record and geochemical data. Sedimentary deposits in the Golfito Complex and younger overlap sequences are indicative of a nearvolcanic, shelf environment from the Campanian ( $\sim 75 \mathrm{Ma})$ to present, distinct from intraoceanic settings generally characteristic of oceanic plateaus [e.g., Kerr, 2003]. Furthermore, quartz grains and tuffaceous deposits in the sediments of the Golfito Formation provide evidence for close, subaerial intermediate-silicic volcanism at least in part contemporaneous with formation of the Golfito Complex. Such volcanism has not been reported so far in typical oceanic plateaus. Finally, major, minor and some trace element contents range from those typical of oceanic plateaus, such as the Nicoya Complex and the bulk of the CLIP, to those similar to subductionrelated volcanic rocks (Figure 6).

[39] We propose the bulk of the Golfito lavas were formed above a nascent subduction zone along the margin of an oceanic plateau. Liquids were produced by introduction of slab-derived fluids into a 

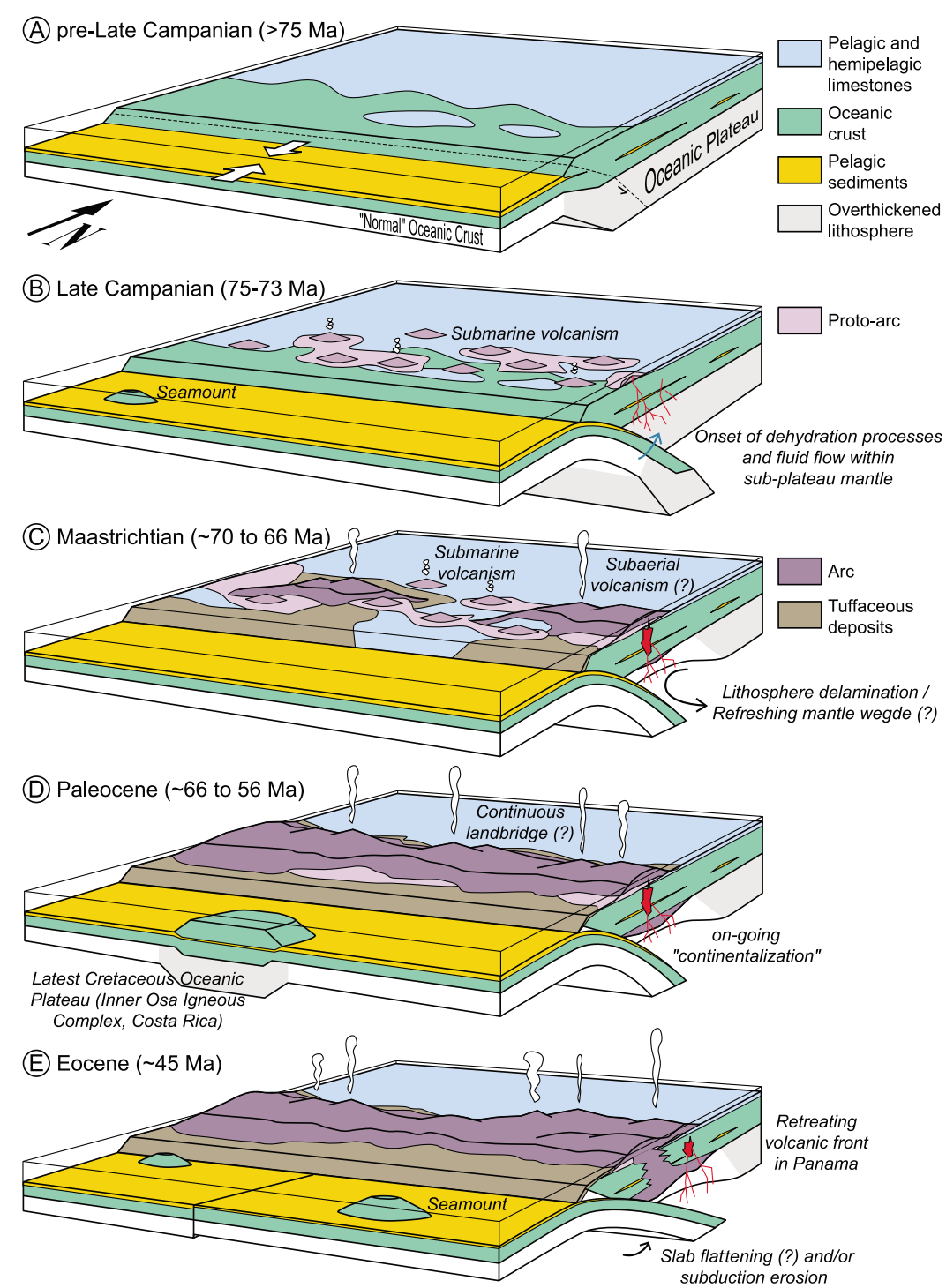

Figure 9. Model of the arc development in south Central America between the Late Cretaceous and the Eocene. (a) Situation prior to the arc initiation, with the Coniacian-early Santonian ( 89-85 Ma) Azuero Plateau resting on "normal" oceanic crust. Arrows indicate possible compression along the edge of the plateau in the late Campanian. (b) Onset of subduction initiation along the Azuero Plateau in the late Campanian ( 75-73 Ma). Dehydrating slab causes melting of the subplateau mantle. (c) Maturation of the arc and partial development of subaerial volcanism in the Maastrichtian. (d) Further maturation of the arc and possible continentalization of the Azuero Plateau in the Paleocene. Incoming of an exotic, latest Cretaceous oceanic plateau that accretes to form the Inner Osa Igneous Complex (southern Costa Rica). (e) In western Panama, subduction erosion and possible slab flattening induces a migration of the arc front toward the Caribbean in the middle Eocene ( $45 \mathrm{Ma}$ ) [Lissinna et al., 2002]. The bulk of the Azuero Accretionary Complex accretes after the migration of the arc front, more or less concurrently with the emplacement of the Outer Osa Igneous Complex (southern Costa Rica).

fertile, persistently hot mantle associated with the oceanic plateau (Figure 9). This model accounts well for the most important features of the Golfito Complex: (1) the stratigraphy is consistent with nearshore, contemporaneous emplacement of mafic and intermediate-silicic volcanism; (2) the Golfito lavas are associated with some of the oldest sediments derived from silicic volcanism in southern
Costa Rica; (3) igneous rocks define a differentiation trend characterized by an increase of silica content in most evolved samples, which may have been controlled by early fractionation of iron oxides; (4) some samples have typical suprasubduction signatures with negative $\mathrm{Nb}-\mathrm{Ti}$ anomalies on a PM-normalized multielementary diagram; (5) most of the igneous rocks have incompatible element 
contents (e.g., $\mathrm{Nb}, \mathrm{Ti}, \mathrm{La}$ and $\mathrm{Sm}$ ) intermediate between oceanic plateaus and intraoceanic arcs (Figures 6-8); and (6) the Golfito Complex was probably deposited on top of an oceanic plateau (see below). Furthermore, the trace element characteristics of fresh clinopyroxene analyzed by La-ICP-MS clearly point toward a suprasubduction signature in some of the igneous rocks of the Golfito Complex [Buchs, 2008]. Immobile radiogenic isotopes data by Hauff et al. [2000] (i.e., Sm$\mathrm{Nd}$ system) and our results from western Panama (see below) are consistent with this interpretation.

[40] Samples GO4 [Hauff et al., 2000] and DB02080 (this study) are geochemically distinct from other igneous samples of the Golfito Complex and are characterized by major, minor and trace element contents similar to typical oceanic plateaus (Figures 6,7a, and 8a). These two samples were recovered from one of the major fault zones in Golfito, in the lowest parts of the exposed volcanic sequence [Mende and Astorga, 2007; Buchs, 2008]. We propose samples GO4 and DB02-080 represent the upper parts of an oceanic plateau forming the basement of the Golfito Complex. This oceanic plateau may be part of an extension of the Azuero Plateau, as suggested by tectonostratigraphic similarities between the Golfito Complex and Azuero Marginal Complex (see below).

\subsection{Origins of the Azuero Marginal Complex}

[41] We interpret the Azuero Marginal Complex as an autochthonous sequence containing from bottom to top (1) the Azuero Plateau, a Coniacianearly Santonian (89-85 Ma) oceanic plateau; (2) the Late Cretaceous Ocú Formation locally interlayered with the Azuero Protoarc Group; (3) the Azuero Protoarc Group that represents protoarc igneous rocks emplaced within and on top of the Azuero Plateau; and (4) the Azuero Arc Group representing a mature arc developed on top of the Azuero Protoarc Group, Ocú Formation, and Azuero Plateau.

[42] On the basis of major, minor and trace element similarities, the Azuero Plateau is interpreted to be an oceanic plateau, as previously suggested for some igneous rocks of the area by Lissinna [2005] (Figures 6-8). Igneous rocks from the Group I form the bulk of the exposed Azuero Plateau and are characterized by typical plateau-like affinities, whereas those of the Group II are restricted to a minor part of the unit (NW of Playa Venado) and display enriched signatures interpreted to reflect melting of an enriched source component. Sedimentary and stratigraphic observations indicate high rates of eruption in a pelagic environment, consistent with an oceanic plateau origin. High$\mathrm{MgO}$ lavas identified in the deeper parts of some plateaus [e.g., Kerr, 2003] have not been observed in the area; present exposures likely represent only the upper layers of the original Azuero Plateau. The age of the Azuero Plateau is defined based on biochronologic data to the Coniacian-early Santonian ( 89-85 Ma) [Kolarsky et al., 1995; Buchs et al., 2009]. ${ }^{40} \mathrm{Ar} /{ }^{39} \mathrm{Ar}$ ages of basalts obtained by incremental heating are overall in good agreement with a Coniacian-early Santonian age of formation for the bulk of the Azuero Plateau [Lissinna, 2005]. Older $\mathrm{K} / \mathrm{Ar}$ date of $\sim 98 \mathrm{Ma}$ reported for a basalt of Playa Venado [Bourgois et al., 1982] may indicate the South Azuero Peninsula includes an older plateau sequence, as also suggested by local occurrence of compositionally unusual basalts and gabbros of the Group II. A younger $71.3 \pm 2.1 \mathrm{Ma}{ }^{40} \mathrm{Ar} /{ }^{39} \mathrm{Ar}$ date obtained by total matrix fusion of a low-K basalt in Soná Peninsula [Hoernle et al., 2002] has probably been affected by loss of radiogenic Ar and, thus, represents only a minimal possible age of formation for the Azuero Plateau. Similar losses of radiogenic Ar have been identified in accreted sequences in south Costa Rica on the basis of tectonostratigraphic and biochronologic data [Buchs et al., 2009]. Clearly, the tectonostratigraphy of the Golfito Complex and Azuero Marginal Complex indicates formation of the Azuero Plateau ceased prior to emplacement of protoarc igneous rocks.

[43] A protoarc origin for the Azuero Protoarc Group is supported by stratigraphic observations and geochemical observations. It is clear from our field observations this Group was emplaced within and on top of the Azuero Plateau through the late Campanian $(\sim 75-73 \mathrm{Ma})$, most probably $\sim 10 \mathrm{Ma}$ after formation of the youngest sequences of the Azuero Plateau. Although the Azuero Protoarc Group has higher $\mathrm{FeO}^{*}, \mathrm{CaO}$ and $\mathrm{Al}_{2} \mathrm{O}_{3}$ contents than igneous rocks from the Golfito Complex (Figures 6b, 6d, and 6e), the bulk of Azuero Protoarc Group has geochemical characteristics similar to those of the Golfito igneous rocks (Figures 6-8). These characteristics and the stratigraphy are consistent with the hypothesis that the Azuero Protoarc Group is part of a primitive island arc developed on top of the Azuero Plateau. Porphyric texture and mineral accumulation (e.g., zoned feldspar and clinopyroxene) in the igneous rocks of the Azuero Protoarc Group indicates magma chambers developed rapidly in western Panama after subduction initiation. 
[44] The Azuero Arc Group has been previously interpreted as an island arc that experienced a complicated evolution between the Maastrichtian and the Eocene [Lissinna, 2005; Wörner et al., 2009; Wegner et al., 2010]. Our geochemical data are in good agreement with this interpretation and indicate the Azuero Arc Group is an assemblage of distinct magmatic suites that remain to be described in detail. Based on our stratigraphic observations, we propose Maastrichtian igneous rocks of the Azuero Arc Group (this study) and a large portion of the "Soná-Azuero Arc" by Wörner et al. [2009] and Wegner et al. [2010] contain mature suprasubduction zone igneous rocks formed mostly after the Azuero Protoarc Group. The earliest evolution of the South Central American Arc was accompanied by development of a restricted volcanic front delineated by silicic intrusives of the Azuero Arc Group (Figure 4). In Costa Rica and Panama, interbeds of protoarc lavas and hemipelagic limestones bearing quartz grains and a tuffaceous component [del Giudice and Recchi, 1969; Obando, 1986; Mende, 2001; this study] suggest earliest arc-related mafic lavas (Azuero Protoarc Group) and silicic lavas (Azuero Arc Group) were at least in part emplaced contemporaneously during the Maastrichtian. Coeval emplacement of arcrelated mafic and acidic lavas in Panama is also supported by similarity of our ages for the Azuero Protoarc Group ( 75-73 Ma) with new ${ }^{40} \mathrm{Ar} /{ }^{39} \mathrm{Ar}$ ages $(67.94 \pm 2.25$ and $71.68 \pm 2.77 \mathrm{Ma})$ obtained by averaged incremental heatings on amphiboles from two dacite samples in the Azuero Arc Group [Wegner et al., 2010].

\section{Arc Initiation in South Central America and Some Implications}

[45] Though $\sim 250 \mathrm{~km}$ distant from each other, the Golfito (southern Costa Rica) and Azuero (western Panama) complexes share several features in terms of their nature and tectonostratigraphic development: (1) the basement of the Azuero Marginal Complex comprises an oceanic plateau, which may also outcrop in the Golfito Complex; (2) the basement of the two complexes is overlapped by igneous rocks interpreted to be a protoarc with atypical affinities developed on top of the oceanic plateau; (3) protoarc igneous rocks of both complexes are partly interbedded with late Campanian-early Maastrichtian hemipelagic limestones that locally comprise a tuffaceous component and epiclasts from an intermediate-silicic volcanic source; (4) the limestones and Late Cretaceous volcano-sedimen- tary sequences from the Caribbean Plate (ODP Leg 165 , sites 999 and 1001) indicate the two complexes and the Caribbean Plate were located under similar, subequatorial paleolatitudes in the Late Cretaceous [Di Marco et al., 1995; Acton et al., 2000]; and (5) the two complexes are overlapped by Maastrichtian to middle Eocene, arc-related volcano-sedimentary sequences and fore-arc sediments. As a consequence, we propose the Golfito Complex and Azuero Marginal Complex are autochthonous sequences preserving the earliest history of the South Central American Arc. The Arc initiated at least in the late Campanian $(\sim 75-73 \mathrm{Ma})$ on top of the Azuero Plateau. The Azuero Plateau forms part of the CLIP, formed during the Conacian-early Santonian ( $\sim 85-83 \mathrm{Ma})$, with possible older magmatic events, and served as a nucleus for accretion of other oceanic plateaus, seamounts, and oceanic islands in south Central America [e.g., Hoernle et al., 2002; Buchs et al., 2009]. Figure 9 illustrates a possible scenario for the arc initiation and subsequent evolution.

[46] The CLIP in south Central America (i.e., Azuero Plateau) is principally composed of basalts with plateau-like affinities, and minor amounts of enriched basalts and gabbros that display some similarities in terms of incompatible element contents with Caribbean basalts at ODP Site 151 (Figure 6f). As already pointed out by many contributions [e.g., Révillon et al., 2002; Kerr et al., 2009], occurrence of depleted and enriched igneous rocks in the CLIP supports existence of a heterogeneous mantle source for the formation of the plateau. However, scarce exposures of enriched igneous rocks in the Azuero Plateau, high consistency of REE contents in protoarc igneous rocks between southern Costa Rica and western Panama, and scarcity of enriched CLIP basalts in the circumCaribbean, suggest the following: (1) plateau-like liquids are the principal melting product of fertile CLIP mantle in south Central America and (2) the mantle wedge at the onset of subduction was essentially homogenous. Distinct differentiation trends of protoarc magmas in Costa Rica and western Panama reflect along-strike heterogeneity of petrologic processes, which we interpret as a possible response to a compositionally heterogeneous subducting plate, distinct directions and rates of subduction of the slab, and/or crustal thickness variations of the Azuero Plateau at the onset of subduction.

[47] Ages of interlayered sediments in protoarc igneous lavas of the Golfito Complex and Azuero Marginal Complex [del Giudice and Recchi, 1969; 
Di Marco et al., 1995; this study] and ${ }^{40} \mathrm{Ar} /{ }^{39} \mathrm{Ar}$ dates [Lissinna, 2005; Wegner et al., 2010] indicate the protoarc evolved rapidly (possibly in less than $5 \mathrm{Ma}$ ) toward a mature volcanic arc represented by the earliest silicic lava flows and intrusives of the Azuero Arc Group. Fragments of larger benthic (shallow water) foraminiferans in the Ocú Formation [del Giudice and Recchi, 1969] (Appendix C) indicate early arc volcanism occurred partly under subaerial conditions in the Campanian-Maastrichtian. Occurrence of quartz grains and/or greenish clinopyroxenes in hemipelagic limestones of the Golfito Formation [Mende, 2001; Buchs, 2008] and Ocú Formation (Appendix C) supports reworking of acidic igneous rocks from the Azuero Arc Group and an unknown equivalent in southern Costa Rica during emplacement of at least some of the protoarc mafic igneous rocks. These observations suggest that, in detail, the transition from a mafic protoarc toward a felsic, more mature arc have been complicated, with partly overlapping emplacement of these two types of arc-related igneous rocks. Such an overlap is in agreement with our model that implies progressive compositional evolution of the mantle wedge during early subduction in response to reorganization of the mantle flow and introduction of slab-derived fluids into the mantle (Figure 9).

[48] Undated (probably latest Cretaceous) igneous rocks with protoarc signatures similar to protoarc rocks of western Panama and southern Costa Rica have been sampled in the Chagres area, and interpreted as part of the early South Central American Arc [Wörner et al., 2005, 2009; Wegner et al., 2010]. Based on geochemical data by Wörner et al. [2009] we believe that protoarc-like igneous rocks of the Chagres area pertain to the earliest arc sequences and, as a consequence, occurrence of these igneous rocks may indicate the Azuero Plateau extend to central Panama and underlies a $\sim 500 \mathrm{~km}$ along-strike arc segment.

[49] Exact origins of the onset of subduction along the SW margin of the Caribbean Plate are obscure. However, it has been demonstrated rheologic contrasts in the lithosphere along the edges of oceanic plateaus [Niu et al., 2003] or intraoceanic transforms [e.g., Toth and Gurnis, 1998; Hall et al., 2003; Stern, 2004] may trigger the onset of subduction if they are associated with a compressive tectonic regime. This suggests the onset of subduction along the SW Caribbean Plate was facilitated by the arrival of the Azuero Plateau. We propose subduction was initiated as a response to compression of the thickened Caribbean Plate during westward migration of the Americas [e.g., Pindell et al., 2005, 2006; Mann, 2007]. Compression along the Plateau may have been facilitated by collision of the thickened Caribbean Plate with South America [Luzieux et al., 2006; Vallejo et al., 2006; Vallejo, 2007].

[50] Finally, we point out the exposures in the western Panamanian and southern Costa Rican fore arc provide a significant opportunity to explore the role of oceanic plateaus in the growth of continental crust. Some models have proposed early coalescence or accretion of oceanic plateaus overprinted by suprasubduction processes may be critical in the development of the continental crust [e.g., Kroenke, 1974; Ben-Avraham et al., 1981; Niu et al., 2003; Kerr and Mahoney, 2007]. Exposures in south Central America can provide the opportunity to investigate the link between oceanic plateaus and the continental crust by stressing out the foundering role of LIPs at convergent margins. Studying petrologic processes leading to crustal thickening of LIPs in suprasubduction zone environments, and estimating volumes of mafic and silicic magma produced through time with characterization of related changes of the bulk crustal composition is fundamental to assess possible roles of oceanic plateaus during formation of the continental crust. We believe this study can be carried out in the Azuero area through integration of new detailed field observations, datings and geochemical analyses of the Azuero Plateau, Azuero Protoarc Group and early Azuero Arc Group.

\section{Summary and Conclusions}

[51] The Golfito Complex includes (1) a (pre-)late Campanian igneous basement, (2) a late Campanian to Maastrichtian volcano-sedimentary formation, and (3) younger fore-arc sedimentary deposits. The Golfito Complex is possibly underlain by an oceanic plateau defined in western Panama as the Azuero Plateau. Lower sequences of the Golfito Complex are interpreted as a protoarc that developed on top of an oceanic plateau between the late Campanian and the Maastrichtian ( 75-66 Ma). In the Maastrichtian and Paleogene, protoarc magmatism ceased in the Golfito area which was progressively buried under younger deposits derived from a maturing volcanic arc nearby.

[52] The Azuero Marginal Complex is composed of (1) an autochthonous basement made of a Coniacianearly Santonian ( 89-85 Ma) oceanic plateau, (2) a late Campanian ( 75-73 Ma) to Maastrichtian protoarc emplaced on top of the plateau, (3) a Late 
Cretaceous to Eocene ( 70 to $45 \mathrm{Ma}$ ) arc that followed the development of the protoarc, and (4) a younger regional overlap sequence. A late Campanian to Maastrichtian (?) protoarc formed on top of a Coniacian-early Santonian ( 89-85 Ma) oceanic plateau defined here as the "Azuero Plateau." In the Maastrichtian, the protoarc was progressively replaced by a more mature arc.

[53] Arc initiation in south Central America occurred in the late Campanian ( 75-73 Ma) along the Late Cretaceous ( 89-85 Ma) Azuero Plateau.

[54] The onset of subduction along the Azuero Plateau produced unusual suprasubduction igneous rocks that are exposed from southern Costa Rica to western Panama (this study) and central Panama [Wörner et al., 2009]. These rocks are part of protoarc sequences. Protoarc igneous rocks are characterized by unusual geochemical compositions intermediate between typical oceanic plateaus and intraoceanic island arcs. Due to high thermal gradients in the subplateau lithosphere at the onset of arc magmatism, and variable influences of slabderived fluids in the earliest suprasubduction magmas, some protoarc igneous rocks are very similar, and sometimes almost indistinguishable, from typical oceanic plateaus.

[55] Dykes of protoarc igneous rocks within the Azuero Plateau and occurrences of protoarc igneous rocks from southern Costa Rica to central Panama are indicative of an oceanic plateau forming the basement of the South Central American Arc. The Azuero Plateau may extend further toward the Colombian Basin and relate to the thickened Caribbean crust. It served as a nucleus for accretion of oceanic plateaus, oceanic islands, and seamounts of Pacific origins.

[56] In the Azuero Marginal Complex, a unique sequence is preserved composed of an oceanic plateau at the base and younger arc-related intrusive and extrusive rocks emplaced into and above the plateau. This provides the rare opportunity to explore possible petrologic mechanisms linking oceanic plateaus to continental evolution.

\section{Appendix A: Supplemental Information Related to the Laser Ablation ICP-MS Analysis of Lithium Tetraborate Glasses}

[57] The analysis of lithium tetraborate glasses was carried out according to the existing practice [Sylvester, 2001; Eggins, 2003], implying that the background intensities were measured as a "gas blank." This method does not account for impurities contained in the lithium tetraborate itself and is only admissible provided the lithium tetraborate contains nearly no trace element impurities.

[58] The quality of lithium tetraborate $\left(\mathrm{Li}_{2} \mathrm{~B}_{4} \mathrm{O}_{7}\right)$ used for the preparation of lithium tetraborate glasses likely depends upon manufacturer. In our laboratories, Lithium Tetraborate Spectromelt A 10 from Merck, Cat. Nr. 1.10783.5000, is used. We regularly test its quality by LA-ICPMS using either blank glasses containing $100 \%$ of lithium tetraborate or glasses doped with silica $\left(16.67 \% \mathrm{SiO}_{2}, 83.33 \%\right.$ $\left.\mathrm{Li}_{2} \mathrm{~B}_{4} \mathrm{O}_{7}\right)$. The results of one such test are given in Table A1.

[59] These are typical results reflecting the quality of lithium tetraborate used in our laboratories. Li was used for internal standardization, its value having been estimated based on the stoichiometry of lithium tetraborate. The SRM 610 glass from NIST was used for external standardization. Whether $\mathrm{Li}$ is a good internal standard for most elements can, of course, be discussed (see Eggins [2003]), as well as the propagation of errors during the calculation, as the average $\mathrm{Li}_{2} \mathrm{O}$ and $\mathrm{B}_{2} \mathrm{O}_{3}$ contents in the SRM 610 glass are 0.104 and $0.115 \mathrm{wt} \%$, respectively. The exact values for lithium (and boron, as well as for most other elements) in the SRM 610 glass can also be discussed, together with the quality of our dual detector calibration for boron. The latter was established by the interpolation of the dual calibration coefficients for $\mathrm{Li}^{7}$ and $\mathrm{Na}^{23}$ instead of direct measurement. This compromises the accuracy of boron determinations in samples extremely enriched in boron, such as lithium tetraborate glasses.

[60] However, the technical aspects briefly mentioned above do not change the main outcome of our tests: nearly all trace elements, including such contaminants as $\mathrm{Pb}$ and REE, are very depleted. This is fully consistent with the counting statistics. The background signal intensity for $\mathrm{Pb}$ in the measurements above is $\sim 2.7$ counts per second (cps), while on the ablation peaks, the maximum intensity of $\mathrm{Pb}$ is $<15.3 \mathrm{cps}$. For comparison, a glass containing $10-20 \mathrm{ppm}$ of $\mathrm{Pb}$ on sample basis will yield several thousands cps on the ablation peak provided the adjustment of the laser and the sensitivity of the ICP spectrometer remain unchanged. Basically the same holds true for the REE. Typical background signals for the REE were significantly lower then $2 \mathrm{cps}$, the highest of the ablation peak signals amounted to 56.4 cps.

[61] Only the V and Sc values in rocks depleted in these elements can be seriously influenced by the 
Table A1. Analysis of Blank Glasses Containing 100\% of Lithium Tetraborate or Glasses Doped With Silica ${ }^{\text {a }}$

\begin{tabular}{|c|c|c|c|c|c|c|c|}
\hline Analyte & Mass & Unit & oc29h03 & oc29h04 & oc $29 \mathrm{~h} 05$ & Average & $1 \sigma \mathrm{StD}$ \\
\hline $\mathrm{Li}_{2} \mathrm{O}$ & 6 & wt $\%$ & 17.67 & 17.67 & 17.67 & 17.67 & \\
\hline $\mathrm{Be}$ & 9 & ppm & 0.110 & 0.118 & 0.168 & 0.132 & 0.026 \\
\hline $\mathrm{B}_{2} \mathrm{O}_{3}$ & 10 & wt $\%$ & 78.87 & 77.60 & 74.08 & 76.8 & 2.0 \\
\hline $\mathrm{Al}_{2} \mathrm{O}_{3}$ & 27 & wt $\%$ & 0.0036 & 0.0038 & 0.0037 & 0.0037 & 0.0001 \\
\hline $\mathrm{CaO}$ & 42 & wt $\%$ & 0.059 & 0.077 & 0.063 & 0.066 & 0.008 \\
\hline $\mathrm{Sc}$ & 45 & ppm & 0.442 & 0.449 & 0.311 & 0.401 & 0.063 \\
\hline $\mathrm{V}$ & 51 & ppm & 2.091 & 2.328 & 2.122 & 2.18 & 0.11 \\
\hline $\mathrm{Cr}$ & 53 & ppm & 1.629 & 1.398 & 1.264 & 1.43 & 0.15 \\
\hline $\mathrm{MnO}$ & 55 & wt \% & 0.00002 & $<0.000$ & $<0.000$ & 0.00002 & \\
\hline $\mathrm{Co}$ & 59 & ppm & $<0.013$ & $<0.013$ & $<0.010$ & $<0.013$ & \\
\hline $\mathrm{Ni}$ & 61 & ppm & $<0.604$ & $<0.594$ & $<0.475$ & $<0.604$ & \\
\hline $\mathrm{Cu}$ & 65 & ppm & 0.261 & 0.211 & 0.362 & 0.278 & 0.063 \\
\hline $\mathrm{Zn}$ & 66 & ppm & 3.410 & 3.356 & 3.388 & 3.385 & 0.022 \\
\hline $\mathrm{Ga}$ & 69 & ppm & 0.111 & 0.100 & 0.131 & 0.114 & 0.013 \\
\hline $\mathrm{Rb}$ & 85 & ppm & $<0.027$ & $<0.026$ & $<0.021$ & $<0.027$ & \\
\hline $\mathrm{Sr}$ & 88 & ppm & 0.019 & 0.024 & 0.029 & 0.024 & 0.004 \\
\hline $\mathrm{Y}$ & 89 & ppm & 0.027 & 0.022 & 0.028 & 0.026 & 0.003 \\
\hline $\mathrm{Zr}$ & 90 & ppm & $<0.011$ & 0.015 & 0.010 & 0.013 & 0.003 \\
\hline $\mathrm{Nb}$ & 93 & ppm & $<0.003$ & $<0.003$ & 0.004 & 0.004 & \\
\hline $\mathrm{Cs}$ & 133 & ppm & $<0.010$ & $<0.010$ & $<0.008$ & $<0.010$ & \\
\hline $\mathrm{Ba}$ & 137 & ppm & 1.800 & 2.042 & 1.939 & 1.93 & 0.10 \\
\hline $\mathrm{La}$ & 139 & $\mathrm{ppm}$ & 0.003 & 0.005 & 0.011 & 0.006 & 0.003 \\
\hline $\mathrm{Ce}$ & 140 & ppm & $<0.004$ & $<0.004$ & 0.011 & 0.011 & \\
\hline $\mathrm{Pr}$ & 141 & ppm & $<0.004$ & $<0.004$ & $<0.003$ & $<0.004$ & \\
\hline $\mathrm{Nd}$ & 143 & ppm & 0.009 & $<0.017$ & 0.006 & 0.008 & 0.002 \\
\hline $\mathrm{Sm}$ & 147 & ppm & $<0.014$ & $<0.014$ & $<0.011$ & $<0.014$ & \\
\hline $\mathrm{Eu}$ & 151 & ppm & $<0.003$ & 0.005 & 0.012 & 0.009 & 0.004 \\
\hline $\mathrm{Gd}$ & 157 & ppm & $<0.014$ & $<0.014$ & $<0.011$ & $<0.014$ & \\
\hline $\mathrm{Tb}$ & 159 & ppm & $<0.003$ & 0.003 & 0.005 & 0.004 & 0.001 \\
\hline Dy & 163 & ppm & $<0.010$ & $<0.009$ & $<0.008$ & $<0.010$ & \\
\hline Ho & 165 & ppm & 0.004 & $<0.003$ & $<0.002$ & 0.004 & \\
\hline $\mathrm{Er}$ & 166 & ppm & $<0.005$ & $<0.005$ & $<0.004$ & $<0.005$ & \\
\hline $\mathrm{Tm}$ & 169 & ppm & $<0.006$ & $<0.006$ & $<0.005$ & $<0.006$ & \\
\hline $\mathrm{Yb}$ & 173 & ppm & $<0.009$ & $<0.009$ & $<0.007$ & $<0.009$ & \\
\hline $\mathrm{Lu}$ & 175 & ppm & $<0.002$ & $<0.002$ & $<0.002$ & $<0.002$ & \\
\hline Hf & 178 & ppm & $<0.009$ & $<0.009$ & $<0.007$ & $<0.009$ & \\
\hline $\mathrm{Ta}$ & 181 & ppm & $<0.002$ & $<0.002$ & $<0.002$ & $<0.002$ & \\
\hline $\mathrm{Pb}$ & 208 & ppm & 0.015 & $<0.009$ & 0.012 & 0.014 & 0.002 \\
\hline $\mathrm{Th}$ & 232 & ppm & $<0.002$ & 0.0034 & 0.0032 & 0.0033 & 0.0001 \\
\hline $\mathrm{U}$ & 238 & ppm & $<0.002$ & 0.0026 & $<0.002$ & 0.0026 & \\
\hline
\end{tabular}

${ }^{\mathrm{a}} 16.67 \% \mathrm{SiO}_{2}, 83.33 \% \mathrm{Li}_{2} \mathrm{~B}_{4} \mathrm{O}_{7} .100 \% \mathrm{Li}_{2} \mathrm{~B}_{4} \mathrm{O}_{7}$ glass, Elan $6100 \mathrm{DRC}$ and GeoLas $200 \mathrm{M}, 120 \mu \mathrm{m}$ pit size, $10 \mathrm{~Hz}$, and $140 \mathrm{~mJ} \mathrm{E}_{\text {output }}$. $\mathrm{Al}^{27}$, $\mathrm{V}^{51}, \mathrm{Ca}^{42}$, and $\mathrm{Sc}^{45}$ values may be somewhat elevated due to polyatomic interferences $\left(\mathrm{B}^{11} \mathrm{O}^{16}+, \mathrm{B}^{11} \mathrm{Ar}^{40}+, \mathrm{Li}^{6} \mathrm{Ar}^{36}+\right.$, and $\mathrm{Li}^{7} \mathrm{Ar}^{38}+$, respectively), important only for samples depleted in $\mathrm{Al}, \mathrm{V}, \mathrm{Ca}$, and $\mathrm{Sc}$.

lithium tetraborate matrix. On a quadrupole mass spectrometer, $\mathrm{V}^{51}$ and $\mathrm{Sc}^{45}$ peaks cannot be resolved from those of polyatomic argide ions $\mathrm{B}^{11} \mathrm{Ar}^{40}$ and $\mathrm{Li}^{7} \mathrm{Ar}^{38}$, respectively. Thus, the $\mathrm{V}$ and $\mathrm{Sc}$ values can be overestimated. As the concentration of the $\mathrm{Li}$ and $\mathrm{B}$ argides in the plasma does not depend much on the chemical composition of the rock dissolved in lithium tetraborate, the accuracy of the $\mathrm{V}$ and $\mathrm{Sc}$ values is mainly concerned with the concentrations of these elements in the studied rock. The higher the $\mathrm{V}$ and Sc whole rock concentrations are, the lower is the relative contribution of the $\mathrm{B}^{11} \mathrm{Ar}^{40}$ and $\mathrm{Li}^{7} \mathrm{Ar}^{38}$ related overlaps. In our experience, $\mathrm{V}$ and $\mathrm{Sc}$ whole rock values from $\sim 30-35$ and $8-10 \mathrm{ppm}$ are little influenced by the argide overlaps, at least for the spectrometer optimizations that we use (see apparent $\mathrm{V}$ and Sc contents in Table A1).

[62] We conclude, therefore, that the contents of nearly all trace elements in lithium tetraborate used in our laboratories are very low and cannot affect the measured concentrations for all but the most strongly depleted geological samples (e.g., some peridotites and serpentinites of the oceanic mantle). The trace element contents in the igneous rocks discussed in the manuscript are much higher compared with those in the lithium tetraborate blank glass. 
[63] At the same time, the lead abundances measured by LA-ICPMS are prone to contamination issues. Actually, we sometimes encounter lithium tetraborate glasses that yield unusually high $\mathrm{Pb}$ intensities in the beginning of the ablation peak, with the $\mathrm{Pb}$ intensity decreasing fast toward the end of the ablation interval. $\mathrm{Zn}$ and, less frequently, $\mathrm{Cu}$ can behave similarly to lead. This is surface contamination that can be easily recognized in the ablation signal. The extent of this contamination usually varies within a small piece of the glass $\left(<0.25-0.4 \mathrm{~cm}^{2}\right)$.

[64] We are certain that in many cases this type of contamination is caused by touching the surface to be analyzed with fingers. Zinc is known to be associated with human skin. Furthermore, in those of the contaminated samples that are strongly depleted in phosphorus $\left(<0.1 \mathrm{wt} \% \mathrm{P}_{2} \mathrm{O}_{5}\right.$, typical of many depleted ultrabasic rocks), $\mathrm{P}$ also exhibits an intensity increase in the beginning of the ablation interval, behaving similarly to $\mathrm{Pb}$ and $\mathrm{Zn}$. In P-rich samples, this effect is more difficult to detect. Sometimes, the contamination of the surface with $\mathrm{Pb}$ and $\mathrm{Zn}$ appears to be related to the quality of abrasive materials used to polish the slices of lithium tetraborate glasses before analysis. In our experience, this source of contamination is less important.

[65] We emphasize that the visual inspection of each spectrum during the analysis and further control of the variability of the concentration values for $\mathrm{Zn}$ and $\mathrm{Pb}( \pm \mathrm{Cu}$ and $\mathrm{P})$ are prerequisites during the analysis of lithium tetraborate glasses. If the $\mathrm{Pb}$ and $\mathrm{Zn}$ intensities suggest some level of contamination, even moving the signal integration window toward the end of the ablation interval, an approach questionable by itself, cannot ensure the correctness of the data (though a preablation may help). The only direct and simple way to ensure that $\mathrm{Pb}$ and $\mathrm{Zn}$ values are correct is to have no surface contamination at all. This is the case with all LA-ICPMS measurements carried out for the present manuscript, as $\mathrm{Pb}$ and $\mathrm{Zn}$ never exhibited any abnormal intensity increase in the beginning of the signal, their intensities were nearly parallel to those of other elements during the whole ablation interval and the variability of the $\mathrm{Pb}$ and $\mathrm{Zn}$ values calculated on the basis of three to four measurements per sample was always low.

\section{Appendix B: New Biostratigraphic Ages of the Ocú Formation}

[66] We provide here new biochronologic data with illustration of some taxa (Figure B1). The hemipelagic limestone forming the Ocú Formation (sample 05-0214-02, active quarries south of Ocú, 525844/873241, UTM WGS84) yielded rich and well preserved assemblages of planktic foraminifera. The biochronologic age of the samples can be constrained by the co-occurrence of Globotruncana ventricosa and Globotruncanita elevata to the G. ventricosa and to the lower half of the Radotruncana calcarata Zones [Robaszynski et al., 1984]. This corresponds to a Campanian age, or much of magnetic zone $33 n$ (approximately 79 to $73 \mathrm{Ma}$ ).

[67] The most abundant planktic foraminifera are the serial forms such as Heterohelix spp. with biserial and triserial forms with inflated globular chambers. In the Globotruncanidae, the monokeeled, conical trochospiral forms are dominant and these forms belong to the Globotruncanita genus. We distinguished Globotruncanita stuartiformis and Globotruncanita elevata. We also found some inflated forms with two well developed and widely spaced keels: Globotruncana ventricosa and G. sp. cf. G. hilli. Others identified include Hedbergella holmdelensis and Archaeoglobigerina cretacea.

[68] A Campanian-Maastrichitan age has been proposed for the Ocú Formation by del Giudice and Recchi [1969] on the basis of the following species: Globotruncana lapparenti (ranging from the upper part of the Dicarinella asymetrica Zone to the base of the Globotruncana aegyptica Zone, Santonian to early Maastrichtian), Globotruncana ventricosa (ranging from the $G$. ventricosa Zone to the middle of the Gansserina gansseri Zone, early Campanian to middle Maastrichtian), Rosita contusa (ranging from the upper G. gansseri Zone to the Abadhomphalus mayaroensis Zone, late Maastrichtian). The first two cited species correspond to a range similar to the range of our samples, but the presence of $R$. contusa clearly indicates a late Maastrichtian age.

[69] A hemipelagic limestone attributed to the Ocú Formation from NW Coiba Island (sample DB06114, 415710/844800, UTM WGS84), yielded scarce and fragmented planktic Foraminifera. Although preservation is poor, and entire specimens rare, the presence of Radoglobotruncana calcarata constrains the age of this sample to the $R$. calcarata Zone, corresponding to the late Campanian, upper part of magnetic zone 33n (approximately 75-73 Myr).

[70] Planktic Foraminifera are mixed with spumellarian and multisegmented nasselarian radiolarians. Planomalinidae comprise some forms with low trocospire and a smooth wall, with globular chambers which increase in size rapidly in the last 

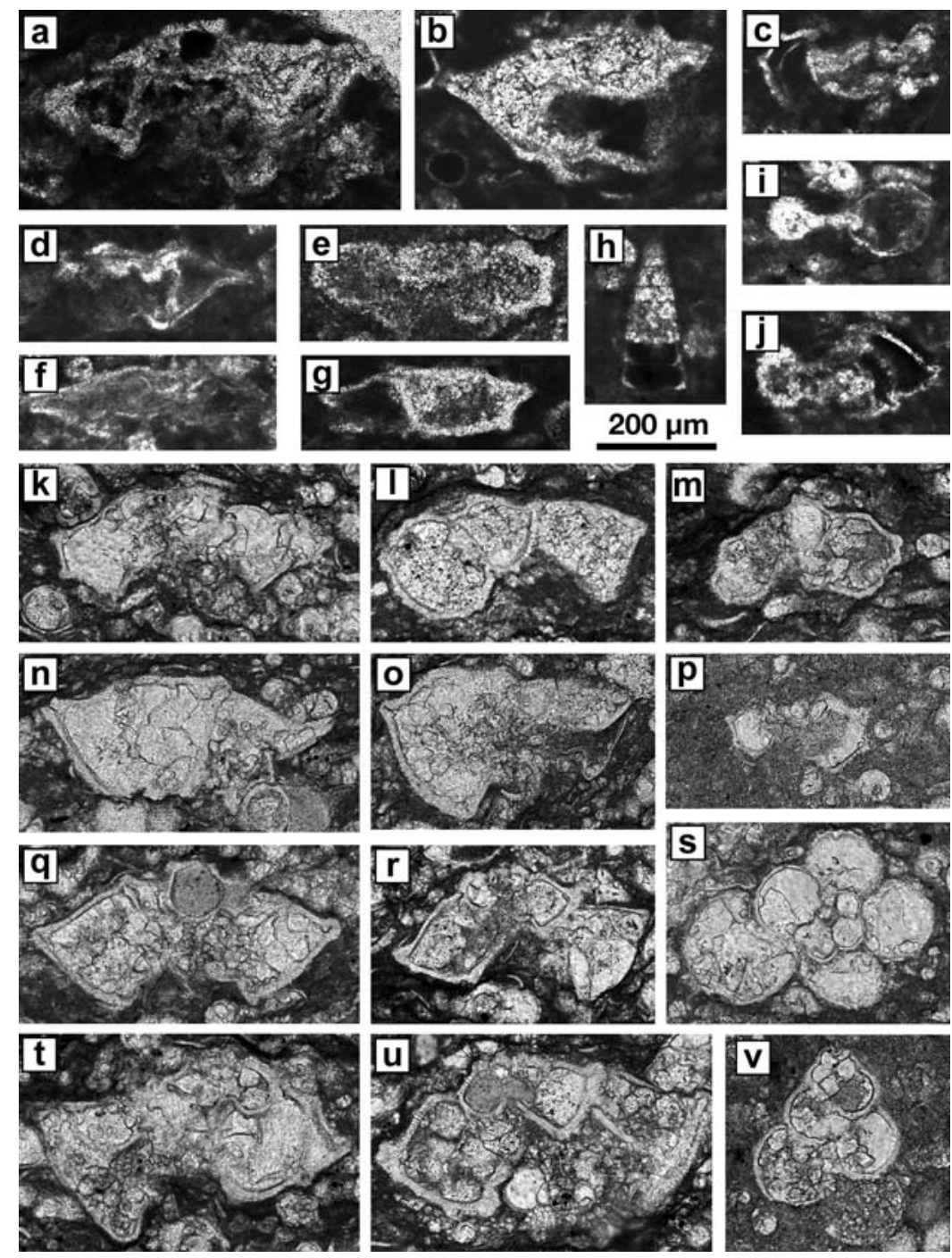

Figure B1. Photomicrographs of Campanian planktic Foraminifera in thin sections. Scale bar for all photomicrographs is $200 \mu \mathrm{m}$. Hemipelagic limestone from the Ocú Formation, sample DB06-114 (Coiba Island). R. calcarata zone, upper Campanian, upper part of magnetic Zone 33n (75-73 Ma). (a) Globotruncanita sp. cf. G. stuartiformis. (b and d) Fragments of Radotruncana calcarata. (c) Fragment of Globotruncana sp. cf. G. fornicata. (e) Globotruncana linneiana. (f) Pseudoguembelina sp. (g) Fragment of G. linneiana. (h) Multicyrtid Nasselaria (radiolarian). (i and j) Globigerinelloides prairiehillensis. Pelagic limestone, sample 05-02-14-02, Ocú Formation, from quarry south of Ocú, lower half of the R. calcarata zone, lower to upper Campanian, magnetic Zone 33n (79 to $73 \mathrm{Myr}$ ): (k) Globotruncana ventricosa, (1) Globotruncana sp. cf. G. hilli Pessagno, (m) Archaeoglobigerina cretacea, (n) Globotruncanita sp. cf. G. elevate, (o) fragment of G. sp. cf. G. elevata, (p) Globotruncana sp. cf. G. lapparenti, (q and r) Globotruncanita sp., (s) Hedbergella holmdelensis Olsson, (t) Globotruncanita elevata (Brotzen), (u) Globotruncanita sp. cf. G. stuartiformis, and (v) Heterohelix globulosa.

whorl. We determined some forms as Globigerinelloides cf. prairiehillensis. The Globotruncanidae are rare but the taxa mentioned above are associated with monokeeled and double keeled flat forms, such as Globotruncana linneiana. Few forms with trapezoidal chambers and slightly convex spiral are also present. Furthermore, we distinguished Globotruncana sp. cf. G. fornicata, Globotruncanita sp. cf. G. stuartiformis, Globo- truncanella sp., Globigerinelloides prairiehillensis, and Pseudoguembelina sp.

\section{Appendix C: Petrographic Characteristics of the Ocú Formation}

[71] The Campanian-Maastrichtian Ocú Formation includes a wide range of lithologies that remain to 

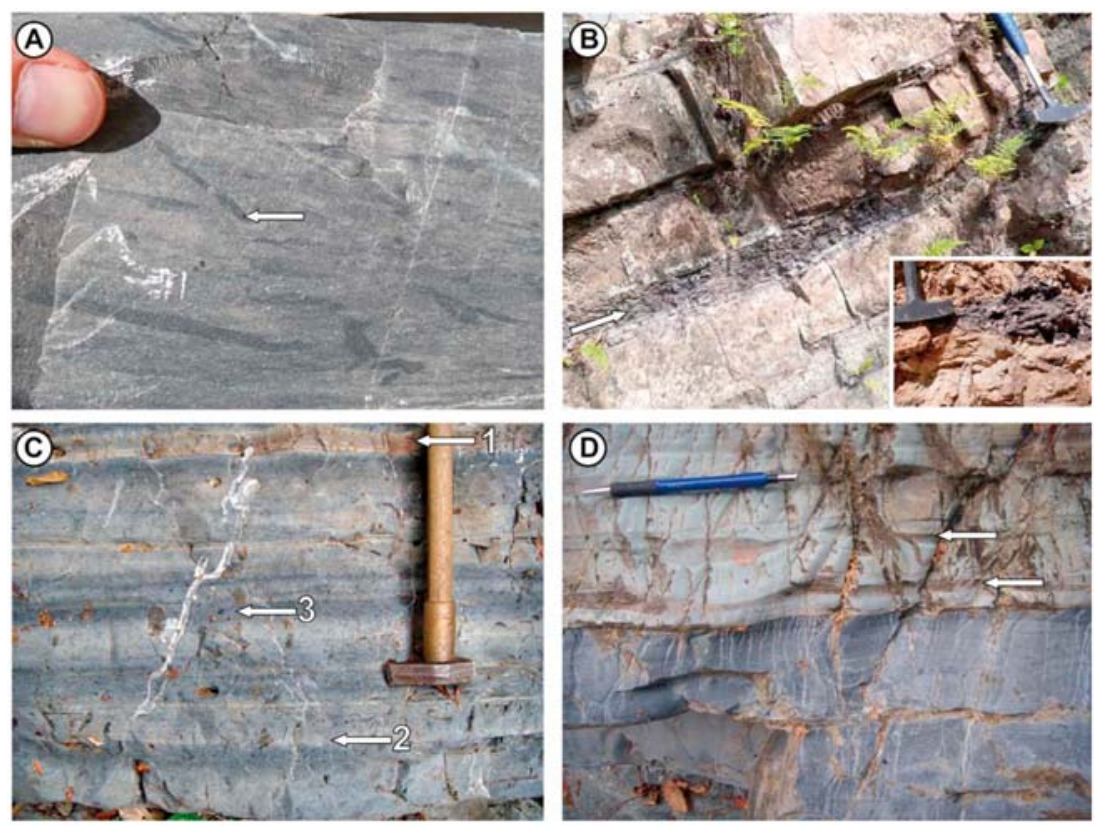

Figure C1. (a) Typical hemipelagic limestone of the Ocú Formation with bioturbations (arrow) (quarry south of Ocú, 525845/873240, UTM WGS84). (b) Hemipelagic limestones with red shale interbed (same locality as Figure C1a). Inset shows altered basaltic pebbles embedded in the red shales. (c) Hemipelagic limestones with detrital layers (indicated by 1), a tuffaceous component (indicated by 2), and a biomicritic component (Río Güerra, 537230/ 834090, UTM WGS84) (indicated by 3). (d) Greenish tuffaceous limestones (top part), with detrital interbeds (arrows), and bioturbated hemipelagic limestone (bottom part) (same locality as Figure C1c). Fragments of shallow water foraminifera have been reported from the same locality by del Giudice and Recchi [1969].

be dated and described in detail. In general, the formation is composed of hemipelagic biomicrite that includes various amounts of clastic and tuffaceous material (Figure C1). The biomicrite is composed of a calcareous matrix that bears planktic foraminifera, radiolaria and sponge spicules (Figure C2a). Reworking and breaking of the fossils is locally observed and probably occurred in response to bottom sea currents. Locally the limestones have an abundant siliceous component of biogenic origin. Bioturbation of the sediment is common.

[72] Tuffaceous and detrital components of the Ocú Formation include sandy and silty grains of plagioclase, pyroxene, quartz, Fe oxide/sulfide minerals, amphibole, fragmented larger benthic (shallow
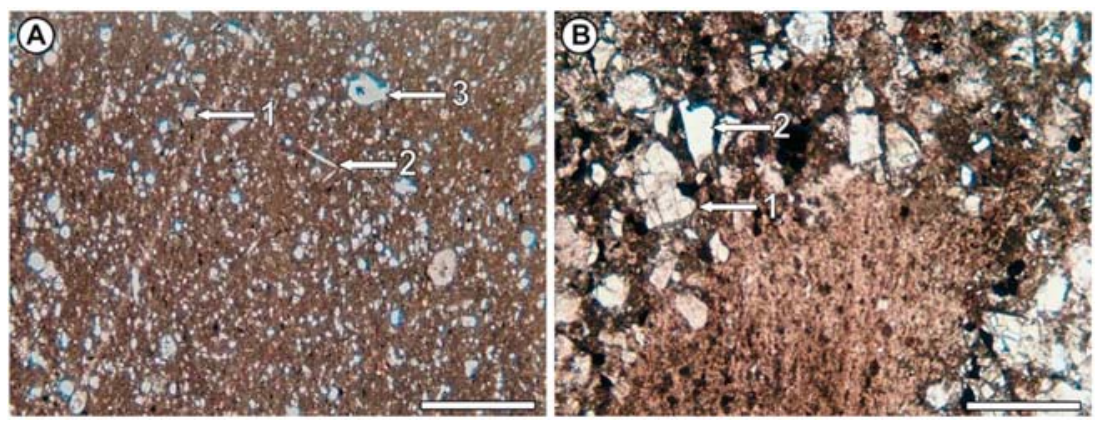

Figure C2. Microscope pictures showing typical compositional end-members of the Ocú Formation (scale bar is $1 \mathrm{~mm}$, transmitted polarized light). (a) Biomicrite with planktic foraminifera and radiolaria (indicated by 1), sponge spicules (indicated by 2), and scarce broken larger benthic foraminifera (road Tonosí-La Miel, 567790/829855, UTM WGS84) (indicated by 3). (b) Bioturbated arenite and biomicrite. The arenite includes greenish clinopyroxenes not observed in the Azuero Plateau (indicated by 1) and feldspar and quartz (upper Río Quebro, Azuero Peninsula) (indicated by 2). 
water) foraminifera, and pumice (Figure C2a). The detrital component is $3-10 \mathrm{~cm}$ sized turbiditic layers (Figure C1c). An ashy component is recognized in the field by a greenish color of the limestone that results from the alteration of glass into chlorite (Figure C1d). Rarely, red shales and rounded basaltic pebbles occur in the limestones, and attest to an increased terrigenous influence (Figure $\mathrm{Clb}$ ).

\section{Acknowledgments}

[73] We thank Guillermo Alvarado, Kaj Hoernle, Esteban Gazel, Vincent Salters, and two anonymous reviewers for their constructive reviews and suggestions on the structure of the paper. We are indebted to Paul Mann for his constructive and accurate review of an earlier version of the manuscript. We also thank Othmar Müntener and Gérard Stampfli for their reviews of an earlier version of this manuscript and discussions that helped to improve the quality of the interpretations. We are grateful to Alberto Ruiz and Gerhard Wörner for sharing unpublished results. Andreas Mende, Kennet Flores, and Alexandre Bandini are thanked for their help during field work. We thank Antonio Velásquez and the Fundación Quebro for their logistic support. This study benefited from the experience of local people, in particular, Ariel Vergara, who helped us carry out field work in difficult conditions. We greatly appreciated motivating discussions with Kaj Hoernle, Folkmar Hauff, and Paul van den Bogaard, who also provided access to the work by Lissinna [2005]. This work was supported by the Swiss National Science Foundation (projects 00021-105845, 200021-105845, and PBLA22-122660), the Herbette Foundation (University of Lausanne), and the Société Académique Vaudoise.

\section{References}

Acton, G. D., et al. (2000), Paleolatitude of the Caribbean Plate since the Late Cretaceous, Proc. Ocean Drill. Program Sci. Results, 165, 149-173.

Adamek, S., C. Frohlich, and W. D. Pennington (1988), Seismicity of the Caribbean-Nazca boundary: Constraints on microplate tectonics of the Panama region, J. Geophys. Res., 93, 2053-2075, doi:10.1029/JB093iB03p02053.

Arculus, R. J. (2003), Use and abuse of the terms calcalkaline and calcalkalic, J. Petrol., 44, 929-935.

Arias, O. (2003), Redefinicion de la Formacion Tulin (Maastrichtiano-Eoceno inferior) del Pacifico Central del Costa Rica, Rev. Geol. Am. Cent., 28, 47-68.

Astorga, A. (1987), El Cretácico Superior y el paleógeno de la vertiente pacífica de Nicaragua meridional y Costa Rica septentrional: Origen, evolución y dinámica de las cuencas profundas relacionadas al margen convergente de Centroamérica, licenciatura thesis, 115 pp., Univ. de Costa Rica, San José, Costa Rica.

Auger, L., G. Abers, E. Syracuse, K. Fischer, W. Strauch, and M. Protti (2007), Crustal Thickness of the Central American Arc, paper presented at Workshop to Integrate Subduction Factory and Seismogeneic Zone Studies in Central America, MARGINS, Heredia, Costa Rica.

Bandini, A. N., K. Flores, P. O. Baumgartner, S.-J. Jackett, and P. Denyer (2008), Late Cretaceous and Paleogene radi- olaria from the Nicoya Peninsula, Costa Rica: A tectonostratigraphic application, Stratigraphy, 5, 3-21.

Bandy, O. L., and R. E. Casey (1973), Reflector horizons and paleobathymetric history, eastern Panama, Geol. Soc. Am. Bull., 84, 3081-3086, doi:10.1130/0016-7606(1973) 84<3081:RHAPHE $>2.0$. CO 2 .

Baumgartner, P. O., C. R. Mora, J. Butterlin, J. Sigal, G. Glacon, J. Azéma, and J. Bourgois (1984), Sedimentación y paleogeografía del Cretácico y Cenozoico del litoral pacífico de Costa Rica, Rev. Geol. Am. Cent., 1, 57-136.

Baumgartner, P. O., K. Flores, A. Bandini, F. Girault, and D. Cruz (2008), Upper Triassic to Cretaceous radiolaria from Nicaragua and northern Costa Rica-The Mesquito Composite Oceanic Terrane, Ofioliti, 33, 1-19.

Ben-Avraham, Z., A. Nur, D. Jones, and A. Cox (1981), Continental accretion-From oceanic plateaus to allochthonous terranes, Science, 213,47-54, doi:10.1126/science.213.4503.47.

Bourgois, J., et al. (1982), Ages and structures of the basic and ultrabasic complexes of the Pacific coast between $3^{\circ} \mathrm{N}$ and $12^{\circ} \mathrm{N}$ (Colombia, Panama and Costa Rica), Bull. Soc. Geol. Fr., 24, 545-554.

Bowland, C. L. (1993), Depositional history of the western Colombian Basin, Caribbean Sea, revealed by seismic stratigraphy, Geol. Soc. Am. Bull., 105, 1321-1345, doi:10.1130/ 0016-7606(1993)105<1321:DHOTWC >2.3.CO;2.

Bowland, C. L., and E. Rosencrantz (1988), Upper crustal structure of the western Colombian Basin, Caribbean Sea, Geol. Soc. Am. Bull., 100, 534-546, doi:10.1130/00167606(1988) $100<0534:$ UCSOTW>2.3.CO;2.

Buchs, D. M. (2008), Late Cretaceous to Eocene geology of the south Central American forearc area (southern Costa Rica and western Panama): Initiation and evolution of an intra-oceanic convergent margin, Ph.D. thesis, 238 pp., Univ. of Lausanne, Lausanne, Switzerland.

Buchs, D. M., P. O. Baumgartner, C. Baumgartner-Mora, A. N. Bandini, S.-J. Jackett, M.-O. Diserens, and J. Stucki (2009), Late Cretaceous to Miocene seamount accretion and mélange formation in the Osa and Burica peninsulas (southern Costa Rica): Episodic growth of a convergent margin, in The Origin and Evolution of the Caribbean Plate, edited by K. H. James, M. A. Lorente, and J. L. Pindell, Geol. Soc. Spec. Publ., 328, 411-456.

Burke, K. (1988), Tectonic evolution of the Caribbean, Annu. Rev. Earth Planet. Sci., 16, 201-230, doi:10.1146/annurev. ea.16.050188.001221.

Calvo, C., and A. Bolz (1994), Der alteste kalkalkaline Inselbogen-Vulcanismus in Costa Rica. Pyroklastite der Formation Loma Chúmico (Alb bis Campan), Profil, 7, 235-264.

Carr, M. J., I. Saginor, G. E. Alvarado, L. L. Bolge, F. N. Lindsay, K. Milidakis, B. D. Turrin, M. D. Feigenson, and C. C. Swisher (2007), Element fluxes from the volcanic front of Nicaragua and Costa Rica, Geochem. Geophys. Geosyst., 8, Q06001, doi:10.1029/2006GC001396.

Cowan, H., M. N. Machette, K. M. Haller, and R. L. Dart (1998), Map and database of Quaternary faults and folds in Costa Rica and its offshore regions, U.S. Geol. Surv. Open File Rep., 98-779, 41 pp. (Available at http:/greenwood.cr.usgs.gov/ pub/open-file-reports/ofr-98-0779/ofr98-779.pdf)

de Boer, Z. J., M. S. Drummond, M. J. Bordelon, M. J. Defant, H. Bellon, and R. C. Maury (1995), Cenozoic magmatic phases of the Costa Rican island arc (Cordillera de Talamanca), in Geologic and Tectonic Development of the Caribbean Plate Boundary in Southern Central America, Spec. Pap. Geol. Soc. Am., 295, 35-55. 
Deering, C. D., T. A. Vogel, L. C. Patino, and G. E. Alvarado (2007), Origin of distinct silicic magma types from the Guachipelin Caldera, NW Costa Rica: Evidence for magma mixing and protracted subvolcanic residence, J. Volcanol. Geotherm. Res., 165, 103-126, doi:10.1016/j.jvolgeores. 2007.05.004.

del Giudice, D., and G. Recchi (1969), Geología del area del projecto minero de Azuero. Ejectora, informe tecnico, 48 pp., Gobierno de la Repub. de Panamá, Panama City.

Dengo, G. (1962), Tectonic-igneous sequence in Costa Rica, in Petrologic Studies: A Volume in Honor of A. F. Buddington, edited by A. E. J. Engel, H. L. James, and B. F. Leonard, pp. 133-161, Geol. Soc. of Am., New York.

Denyer, P., and G. E. Alvarado (2007), Mapa geológico de Costa Rica, scale 1:400,000, Libr. Francesa S.A., San José.

Denyer, P., and E. Gazel (2009), The Costa Rican Jurassic to Miocene oceanic complexes: Origin, tectonics and relations, J. South Am. Earth Sci., 28, 429-442, doi:10.1016/j. jsames.2009.04.010.

Denyer, P., P. O. Baumgartner, and E. Gazel (2006), Characterization and tectonic implications of Mesozoic-Cenozoic oceanic assemblages of Costa Rica and western Panama, Geol. Acta, 4, 219-235.

Di Marco, G. (1994), Les terrains accrétés du Costa Rica: Évolution teconostratigraphique de la marge occidentale de la Plaque Caraïbe, Mem. Geol., vol. 20, 20 pp., Univ. de Lausanne, Lausanne, Switzerland.

Di Marco, G., P. O. Baumgartner, and J. E. T. Channell (1995), Late Cretaceous-early Tertiary paleomagnetic data and a revised tectonostratigraphic subdivision of Costa Rica and western Panama, in Geologic and Tectonic Development of the Caribbean Plate Boundary in Southern Central America, edited by P. Mann, Spec. Pap. Geol. Soc. Am., 295, 1-27.

Dirección General de Recursos Minerales (1991), Panama geologic map (Mapa Geológico República de Panamá), scale 1:250,000, Panama City.

Eggins, M. S. (2003), Laser ablation ICP-MS analysis of geological materials prepared as lithium borate glasses, Geostand. Geoanal. Res., 27, 147-162.

Feigenson, M. D., M. J. Carr, S. V. Maharaj, S. Juliano, and L. L. Bolge (2004), Lead isotope composition of Central American volcanoes: Influence of the Galapagos plume, Geochem. Geophys. Geosyst., 5, Q06001, doi:10.1029/2003GC000621.

Fisher, D. M., T. W. Gardner, J. S. Marshall, P. B. Sak, and M. Protti (1998), Effect of subducting sea-floor roughness on fore-arc kinematics, Pacific coast, Costa Rica, Geology, 26, 467-470, doi:10.1130/0091-7613(1998)026<0467: EOSSFR $>2.3 . \mathrm{CO} ; 2$

Fisher, S. P., and E. A. Pessagno Jr. (1965), Upper Cretaceous strata of northwestern Panama, Am. Assoc. Pet. Geol. Bull., $49,433-444$

Flores, K. (2003), Propuesta tectonoestratigráfica de la región septentrional del golfo de Nicoya, Costa Rica, licenciatura thesis, 176 pp., Univ. of Costa Rica, San José, Costa Rica.

Flueh, E. R., and R. von Huene (2007), Crustal structure, in Central America-Geology, Resources and Hazards, edited by J. Bundschuh and G. E. Alvarado, pp. 267-276, Taylor and Francis, Oxford, U. K.

Frisch, W., M. Meschede, and M. Sick (1992), Origin of the Central American ophiolites: Evidence from paleomagnetic results, Geol. Soc. Am. Bull., 104, 1301-1314, doi:10.1130/ 0016-7606(1992)104<1301:OOTCAO >2.3.CO;2.

Gardner, T., et al. (2001), Holocene forearc block rotation in response to seamount subduction, southeastern Peninsula de
Nicoya, Costa Rica, Geology, 29, 151-154, doi:10.1130/ 0091-7613(2001)029<0151:HFBRIR>2.0.CO;2.

Gazel, E., M. J. Carr, K. Hoernle, M. D. Feigenson, D. Szymanski, F. Hauff, and P. van den Bogaard (2009), Galapagos-OIB signature in southern Central America: Mantle refertilization by arc-hot spot interaction, Geochem. Geophys. Geosyst., 10, Q02S11, doi:10.1029/2008GC002246.

Geldmacher, J., K. Hoernle, P. van den Bogaard, F. Hauff, and A. Klügel (2008), Age and geochemistry of the Central American forearc basement (DSDP Leg 67 and 84): Insights into Mesozoic arc volcanism and seamount accretion, J. Petrol., 49, 1781-1815, doi:10.1093/petrology/egn046.

Gurnis, M., C. Hall, and L. Lavier (2004), Evolving force balance during incipient subduction, Geochem. Geophys. Geosyst., 5, Q07001, doi:10.1029/2003GC000681.

Hall, C. E., M. Gurnis, M. Sdrolias, L. L. Lavier, and R. D. Muller (2003), Catastrophic initiation of subduction following forced convergence across fracture zones, Earth Planet. Sci. Lett., 212, 15-30, doi:10.1016/S0012-821X(03)00242-5.

Hauff, F., K. A. Hoernle, P. van den Bogaard, G. E. Alvarado, and D. Garbe-Schonberg (2000), Age and geochemistry of basaltic complexes in western Costa Rica: Contributions to the geotectonic evolution of Central America, Geochem. Geophys. Geosyst., 1(5), 1009, doi:10.1029/1999GC000020.

Hoernle, K., and F. Hauff (2007), Oceanic igneous complexes, in Central America-Geology, Resources and Hazards, edited by J. Bundschuh and G. Alvarado, pp. 523-548, doi:10.1201/9780203947043.ch20, Taylor and Francis, Oxford, U. K.

Hoernle, K., P. van den Bogaard, R. Werner, B. Lissinna, F. Hauff, G. Alvarado, and D. Garbe-Schonberg (2002), Missing history (16-71 Ma) of the Galapagos hotspot: Implications for the tectonic and biological evolution of the Americas, Geology, 30, 795-798, doi:10.1130/0091-7613(2002) 030<0795:MHMOTG>2.0.CO;2.

Hoernle, K., F. Hauff, and P. van den Bogaard (2004), 70 m.y. history (139-69 Ma) for the Caribbean large igneous province, Geology, 32, 697-700, doi:10.1130/G20574.1.

Hoernle, K., et al. (2008), Arc-parallel flow in the mantle wedge beneath Costa Rica and Nicaragua, Nature, 451, 1094-1097, doi:10.1038/nature06550.

James, K. H. (2006), Arguments for and against the Pacific origin of the Caribbean Plate: Discussion, finding for an interAmerican origin, Geol. Acta, 4, 279-302.

Kerr, A. C. (2003), Oceanic plateaus, in Treatise on Geochemistry, vol. 3, The Crust, edited by R. L. Rudnick, H. D. Holland, and K. K. Turekian, pp. 537-565, Elsevier, Amsterdam.

Kerr, A. C. (2005), La Isla de Gorgona, Colombia: A petrological enigma?, Lithos, 84, 77-101, doi:10.1016/j.lithos. 2005.02.006.

Kerr, A. C., and J. J. Mahoney (2007), Oceanic plateaus: Problematic plumes, potential paradigms, Chem. Geol., 241, 332-353, doi:10.1016/j.chemgeo.2007.01.019.

Kerr, A. C., J. Tarney, P. D. Kempton, P. Spadea, A. Nivia, G. F. Marriner, and R. A. Duncan (2002), Pervasive mantle plume head heterogeneity: Evidence from the late Cretaceous Caribbean-Colombian oceanic plateau, J. Geophys. Res., 107(B7), 2140, doi:10.1029/2001JB000790.

Kerr, A. C., D. G. Pearson, and G. M. Nowell (2009), Magma source evolution beneath the Caribbean oceanic plateau: New insights from elemental and $\mathrm{Sr}-\mathrm{Nd}-\mathrm{Pb}-\mathrm{Hf}$ isotopic studies of ODP Leg 165 Site 1001 basalts, in The Origin and Evolution of the Caribbean Plate, edited by K. H. James, M. A. Lorente, and J. L. Pindell, Geol. Soc. Spec. Publ., 328, 809-827. 
Kolarsky, R. A., P. Mann, S. Monechi, H. D. Meyerhoff, and E. A. Pessagno Jr. (1995), Stratigraphic development of southwestern Panama as determined from integration of marine seismic data and onshore geology, in Geologic and Tectonic Development of the Caribbean Plate Boundary in Southern Central America, edited by P. Mann, Spec. Pap. Geol. Soc. Am., 295, 159-200.

Kroenke, L. W. (1974), Origin of continents through development and coalescence of oceanic flood basalt plateaus, Eos Trans. $A G U, 55,443$.

Lissinna, B. (2005), A profile though the Central American Landbridge in western Panama: $115 \mathrm{Ma}$ interplay between the Galápagos Hotspot and the Central American Subduction Zone, Ph.D. thesis, 102 pp., Christian-Albrechts-Univ. zu Kiel, Kiel, Germany.

Lissinna, B., K. Hoernle, and P. van den Bogaard (2002), Northern migration of arc volcanism in western Panama: Evidence for subduction erosion?, Eos Trans. AGU, 83, 1463-1464.

Lissinna, B., K. Hoernle, F. Hauff, P. van den Bogaard, and S. Sadofsky (2006), The Panamanian island arc and Galápagos hotspot: A case study for the long-term evolution of arc/ hotspot interaction, Geophys. Res. Abstr., 8, 05106.

Lundberg, N. (1982), Evolution of the slope landward of the Middle America Trench, Nicoya Peninsula, Costa Rica, Geol. Soc. Spec. Publ., 10, 131-147, doi:10.1144/GSL. SP.1982.010.01.9.

Lundberg, N. (1991), Detrital record of the early Central American magmatic arc: Petrography of intraoceanic forearc sandstones, Nicoya Peninsula, Costa Rica, Geol. Soc. Am. Bull., 103, 905-915, doi:10.1130/0016-7606(1991) $103<0905$ :DROTEC $>2.3 . C O ; 2$.

Luzieux, L. D. A., F. Heller, R. Spikings, C. F. Vallejo, and W. Winkler (2006), Origin and Cretaceous tectonic history of the coastal Ecuadorian forearc between $1^{\circ} \mathrm{N}$ and $3^{\circ} \mathrm{S}$ : Paleomagnetic, radiometric and fossil evidence, Earth Planet. Sci. Lett., 249, 400-414, doi:10.1016/j.eps1.2006.07.008.

MacKenzie, L., G. A. Abers, K. M. Fischer, E. M. Syracuse, J. M. Protti, V. Gonzalez, and W. Strauch (2008), Crustal structure along the southern Central American volcanic front, Geochem. Geophys. Geosyst., 9, Q08S09, doi:10.1029/2008GC001991.

MacMillan, I., P. B. Gans, and G. Alvarado (2004), Middle Miocene to present plate tectonic history of southern Central American volcanic arc, Tectonophysics, 392, 325-348, doi:10.1016/j.tecto.2004.04.014.

Mann, P. (2007), Overview of the tectonic history of northern Central America, in Geologic and Tectonic Development of the Caribbean Plate Boundary in Northern Central America, edited by P. Mann, Spec. Pap. Geol. Soc. Am., 428, 1-19, doi:10.1130/2007.2428(01).

Marshall, J. S., D. M. Fisher, and T. W. Gardner (2000), Central Costa Rica deformed belt: Kinematics of diffuse faulting across the western Panama block, Tectonics, 19, 468-492, doi:10.1029/1999TC001136.

Mauffret, A., and S. Leroy (1997), Seismic stratigraphy and structure of the Caribbean igneous province, Tectonophysics, 283, 61-104, doi:10.1016/S0040-1951(97)00103-0.

Maury, R. C., M. J. Defant, H. Bellon, Z. J. de Boer, R. H. Stewart, and J. Cotten (1995), Early Tertiary arc volcanics from eastern Panama, in Geologic and Tectonic Development of the Caribbean Plate Boundary in Southern Central America, edited by P. Mann, Spec. Pap. Geol. Soc. Am., 295, 29-34.

McDonough, W. F., and S. S. Sun (1995), The composition of the Earth: Chemical evolution of the mantle, Chem. Geol., 120, 223-253, doi:10.1016/0009-2541(94)00140-4.
Mende, A. (2001), Sedimente und Architektur der Forearc-und Backarc-Becken von Südost-Costa Rica und NordwestPanamá, Profil, 19, 1-130.

Mende, A., and A. Astorga (2007), Incorporating geology and geomorphology in land management decisions in developing countries: A case study in Southern Costa Rica, Geomorphology, 87, 68-89, doi:10.1016/j.geomorph.2006.06.043.

Meschede, M., and U. Barckhausen (2001), The relationship of the Cocos and Carnegie ridges: age constraints from paleogeographic reconstructions, Int. J. Earth Sci., 90, 386-392.

Meschede, M., and W. Frisch (1998), A plate-tectonic model for the Mesozoic and early Cenozoic history of the Caribbean Plate, Tectonophysics, 296, 269-291, doi:10.1016/ S0040-1951(98)00157-7.

Metti, A., and G. Recchi (1976) Geología de la Peninsula de Soná e Isla de Coiba, in Memoria Segundo Congreso Latinoamericano de Geología, vol. 2, pp. 541-553, Sucre, Caracas.

Montero, W., P. Denyer, R. Barquero, G. E. Alavarado, H. Cowan, M. N. Machette, K. M. Haller, and R. L. Dart (1998), Map and database of Quaternary faults and folds in Costa Rica and its offshore regions, U.S. Geol. Surv. Open File Rep., 98-481, 63 pp. (Available at http://greenwood.cr. usgs.gov/pub/open-file-reports/ofr-98-0481/)

Morell, K. D., D. M. Fisher, and T. W. Gardner (2008), Inner forearc response to subduction of the Panama Fracture Zone, southern Central America, Earth Planet. Sci. Lett., 265, 82-95, doi:10.1016/j.eps1.2007.09.039.

Niu, Y. L., M. J. O'Hara, and J. A. Pearce (2003), Initiation of subduction zones as a consequence of lateral compositional buoyancy contrast within the lithosphere: A petrological perspective, J. Petrol., 44, 851-866, doi:10.1093/petrology/ 44.5.851.

Obando, J. A. (1986), Sedimentología y tectónica del Cretácico y Paleógeno de la region de Golfito, Península de Burica y Península de Osa, Provincia de Puntarenas, Costa Rica, licenciatura thesis, 211 pp., Escuela Centroam. de Geol., Univ. de Costa Rica, San José, Costa Rica.

Paris, G., M. N. Machette, R. L. Dart, and K. M. Haller (2000), Map and database of Quaternary faults and folds in Colombia and its offshore regions, U.S. Geol. Surv. Open File Rep., 00-0284, 60 pp. (Available at http://greenwood.cr.usgs.gov/ pub/open-file-reports/ofr-00-0284/)

Patino, L. C., G. E. Alvarado-Induni, and T. A. Vogel (2004), Early arc magmatism: Geochemical characteristics of volcanic clasts from Punta Sámara, Costa Rica, Rev. Geol. Am. Cent., 30, 117-125.

Pearce, J. A., and D. W. Peate (1995), Tectonic implications of the composition of volcanic arc magmas, Annu. Rev. Earth Planet. Sci., 23, 251-285, doi:10.1146/annurev.ea.23.050195.001343.

Pearce, J. A., S. R. Van der Laan, R. J. Arculus, B. J. Mutton, and T. Ishii (1992), Boninite and harzburgite from Leg 125 (Bonin-Mariana forearc): A case study of magma genesis during the initial stages of subduction, Proc. Ocean Drill. Program Sci. Results, 125, 623-659.

Petterson, M. G., et al. (1999), Geological-tectonic framework of Solomon Islands, SW Pacific: Crustal accretion and growth within an intra-oceanic setting, Tectonophysics, 301, 35-60.

Pindell, J., and L. Kennan (2009), Tectonic evolution of the Gulf of Mexico, Caribbean and northern South America in the mantle reference frame: An update, in The Origin and Evolution of the Caribbean Plate, edited by K. H. James, M. A. Lorente, and J. L. Pindell, Geol. Soc. Spec. Publ., $328,1-55$. 
Pindell, J., L. Kennan, W. V. Maresch, K. P. Stanek, G. Draper, and R. Higgs (2005), Plate kinematics and crustal dynamics of circum-Caribbean arc-continent interactions: Tectonic controls on basin development in proto-Caribbean margins, in Caribbean-South American Plate Interactions, Venezuela, Spec. Pap. Geol. Soc. Am., 394, 7-52.

Pindell, J., L. Kennan, K. P. Stanek, W. V. Maresch, and G. Draper (2006), Foundations of Gulf of Mexico and Caribbean evolution: Eight controversies resolved, Geol. Acta, 4, 303-341.

Ranero, C. R., and R. von Huene (2000), Subduction erosion along the Middle America convergent margin, Nature, 404, 748-752, doi:10.1038/35008046.

Révillon, S., E. Hallot, N. T. Arndt, C. Chauvel, and R. A. Duncan (2000), A complex history for the Caribbean plateau: Petrology, geochemistry, and geochronology of the Beata Ridge, south Hispaniola, J. Geol., 108, 641-661.

Révillon, S., C. Chauvel, N. T. Arndt, R. Pik, F. Martineau, S. Fourcade, and B. Marty (2002), Heterogeneity of the Caribbean plateau mantle source: $\mathrm{Sr}, \mathrm{O}$ and $\mathrm{He}$ isotopic compositions of olivine and clinopyroxene from Gorgona Island, Earth Planet. Sci. Lett., 205, 91-106, doi:10.1016/ S0012-821X(02)01003-8.

Rivier, F. (1983), Síntesis geológica y mapa geológico del área de bajo Tempisque, Guanacaste, Costa Rica, in Informe Semestral, vol. 1, pp. 7-30, Inst. Geogr. Nac., San José.

Robaszynski, F., M. Caron, J. M. Gonzalez Donoso, A. A. H. Wonders, and the European Working Group on Planktonic Foraminifera (1984), Atlas of Late Cretaceous globotruncanids, Rev. Micropaleontol., 26(3-4), 145-305.

Sak, P. B., D. M. Fisher, T. W. Gardner, J. S. Marshall, and P. C. LaFemina (2009), Rough crust, forearc kinematics, and Quaternary uplift rates, Costa Rican segment of the middle American Trench, Geol. Soc. Am. Bull., 121, 9921012, doi:10.1130/B26237.1.

Sallarès, V., J. J. Danobeitia, E. R. Flueh, and G. Leandro (1999), Seismic velocity structure across the middle American landbridge in northern Costa Rica, J. Geodyn., 27, 327344, doi:10.1016/S0264-3707(98)00007-6.

Sallarès, V., J. J. Danobeitia, and E. R. Flueh (2001), Lithospheric structure of the Costa Rican Isthmus: Effects of subduction zone magmatism on an oceanic plateau, J. Geophys. Res., 106, 621-643.

Schmidt-Effing, R. (1979), Alter und Genese des NicoyaKomplexes, einer ozeanischen Palaeokruste (Oberjura bis Eozaen) im suedlichen Zentralamerika, Geol. Rundsch., 68, 457-494, doi:10.1007/BF01820803.

Silver, E. A., D. L. Reed, J. E. Tagudin, and D. J. Heil (1990), Implications of the north and south Panama thrust belts for the origin of the Panama orocline, Tectonics, 9, 261-281, doi:10.1029/TC009i002p00261.

Sinton, C. W., R. A. Duncan, and P. Denyer (1997), Nicoya Peninsula, Costa Rica: A single suite of Caribbean oceanic plateau magmas, J. Geophys. Res., 102, 15,507-15,520, doi:10.1029/97JB00681.

Sinton, C. W., R. A. Duncan, M. Storey, J. Lewis, and J. J. Estrada (1998), An oceanic flood basalt province within the Caribbean plate, Earth Planet. Sci. Lett., 155, 221-235, doi:10.1016/S0012-821X(97)00214-8.

Smith, W. H. F., and D. T. Sandwell (1997), Global sea floor topography from satellite altimetry and ship depth soundings, Science, 277, 1956-1962, doi:10.1126/science. 277.5334.1956.

Stern, R. J. (2004), Subduction initiation: Spontaneous and induced, Earth Planet. Sci. Lett., 226, 275-292.
Su, Y., and C. H. Langmuir (2003), Global MORB chemistry compilation at the segment scale, Ph.D. thesis, Columbia Univ., New York.

Sylvester, P. J. (2001), Trace element analysis of fused whole rock glasses by laser ablation ICPMS, in Laser Ablation ICP-MS in the Earth Sciences, Principles and Applications, edited by P. J. Sylvester, Short Course Ser. Mineral. Assoc. Can., 29, 147-162.

Taboada, A., L. A. Rivera, A. Fuenzalida, A. Cisternas, H. Philip, H. Bijwaard, J. Olaya, and C. Rivera (2000), Geodynamics of the northern Andes: Subductions and intracontinental deformation (Colombia), Tectonics, 19, 787-813, doi:10.1029/2000TC900004.

Toth, J., and M. Gurnis (1998), Dynamics of subduction initiation at preexisting fault zones, J. Geophys. Res., 103, $18,053-18,067$.

Tournon, J. (1984), Magmatisme du Mésozoïque à l'actuel en Amérique Centrale: L'exemple du Costa Rica, des ophiolites aux andésites, Ph.D. thesis, 335 pp., Univ. Pierre et Marie Curie, Paris.

Tournon, J., C. Triboulet, and J. Azéma (1989), Amphibolites from Panama: Anticlockwise P-T paths from a pre-upper Cretaceous metamorphic basement in Isthmian Central America, J. Metamorph. Geol., 7, 539-546, doi:10.1111/ j.1525-1314.1989.tb00616.x.

Trenkamp, R., J. N. Kellogg, J. T. Freymueller, and H. P. Mora (2002), Wide plate margin deformation, southern Central America and northwestern South America, CASA GPS observations, J. South Am. Earth Sci., 15, 157-171, doi:10.1016/S0895-9811(02)00018-4.

Turner, S., and C. Hawkesworth (1997), Constraints on flux rates and mantle dynamics beneath island arcs from Tonga-Kermadec lava geochemistry, Nature, 389, 568573, doi:10.1038/39257.

Vallejo, C. (2007), Evolution of the Western Cordillera in the Andes of Ecuador (Late Cretaceous-Paleogene), Ph.D. thesis, 215 pp., Swiss Fed. Inst. of Technol., Zurich, Switzerland.

Vallejo, C., R. A. Spikings, L. Luzieux, W. Winkler, D. Chew, and L. Page (2006), The early interaction between the Caribbean plateau and the NW South American Plate, Terra Nova, 18, 264-269.

Vogel, T. A., L. C. Patino, G. E. Alvarado, and P. B. Gans (2004), Silicic ignimbrites within the Costa Rican volcanic front: Evidence for the formation of continental crust, Earth Planet. Sci. Lett., 226, 149-159, doi:10.1016/j.eps1. 2004.07.013.

von Huene, R., et al. (1995), Morphotectonics of the Pacific convergent margin of Costa Rica, in Geologic and Tectonic Development of the Caribbean Plate Boundary in Southern Central America, edited by P. Mann, Spec. Pap. Geol. Soc. Am., 295, 291-307.

von Huene, R., C. R. Ranero, W. Weinrebe, and K. Hinz (2000), Quaternary convergent margin tectonics of Costa Rica, segmentation of the Cocos Plate, and Central American volcanism, Tectonics, 19, 314-334, doi:10.1029/ 1999TC001143.

Walther, C. H. E., E. R. Flueh, C. R. Ranero, R. von Huene, and W. Strauch (2000), Crustal structure across the Pacific margin of Nicaragua: Evidence for ophiolitic basement and a shallow mantle sliver, Geophys. J. Int., 141, 759-777, doi:10.1046/j.1365-246x.2000.00134.x.

Wegner, W., G. Wörner, R. S. Harmon, and B. R. Jicha (2010), Magmatic history and evolution of the Central American Land Bridge in Panama since Cretaceous times, Geol. Soc. Am. Bull., doi:10.1130/B30109.1, in press. 
Werner, R., K. Hoernle, P. van den Bogaard, C. Ranero, R. von Huene, and D. Korich (1999), Drowned 14-m.y.-old Galapagos Archipelago off the coast of Costa Rica; implications for tectonic and evolutionary models, Geology, 27, 499-502, doi:10.1130/0091-7613(1999)027<0499:DMYOGP>2.3.CO;2.

Wörner, G., R. S. Harmon, G. Hartmann, and K. Simon (2005), Igneous geology and geochemistry of the upper Río Chagres basin, in The Río Chagres, Panama: A Multidisciplinary Profile of a Tropical Watershed, edited by V. P. Singh and R. S. Harmon, pp. 65-81, Springer, Dordrecht, Netherlands.
Wörner, G., R. S. Harmon, W. Wegner, and B. Singer (2006), Linking America's backbone: Geological development and basement rocks of central Panama, Geol. Soc. Am. Abstr. Programs, 2, 60.

Wörner, G., R. S. Harmon, and W. Wegner (2009), Geochemical evolution of igneous rock and changing magma sources during the evolution and closure of the Central American Landbridge, in Backbone of the Americas, edited by S. Mahlburg et al., Mem. Geol. Soc. Am., 204, 183-196. 